\title{
Rapid-Scan Radar Observations of an Oklahoma Tornadic Hailstorm Producing Giant Hail
}

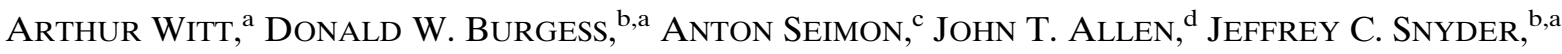 \\ AND HOWARD B. BLUESTEIN ${ }^{\mathrm{e}}$ \\ ${ }^{a}$ NOAA/National Severe Storms Laboratory, Norman, Oklahoma \\ ${ }^{\mathrm{b}}$ Cooperative Institute for Mesoscale Meteorological Studies, University of Oklahoma, Norman, Oklahoma \\ ${ }^{\mathrm{c}}$ Department of Geography and Planning, Appalachian State University, Boone, North Carolina \\ ${ }^{\mathrm{d}}$ Department of Earth and Atmospheric Sciences, Central Michigan University, Mount Pleasant, Michigan \\ ${ }^{\mathrm{e}}$ School of Meteorology, University of Oklahoma, Norman, Oklahoma
}

(Manuscript received 4 January 2018, in final form 24 July 2018)

\begin{abstract}
Rapid-scan radar observations of a supercell that produced near-record size hail in Oklahoma are examined. Data from the National Weather Radar Testbed Phased Array Radar (PAR) in Norman, Oklahoma, are used to study the overall character and evolution of the storm. Data from the nearby polarimetric KOUN WSR-88D and rapid-scanning X-band polarimetric (RaXPol) mobile radar are used to study the evolution of low- to midaltitude dual-polarization parameters above two locations where giant hailstones up to $16 \mathrm{~cm}$ in diameter were observed. The PAR observation of the supercell's maximum storm-top divergent outflow is similar to the strongest previously documented value. The storm's mesocyclone rotational velocity at midaltitudes reached a maximum that is more than double the median value for similar observations from other storms producing giant hail. For the two storm-relative areas where giant hail was observed, noteworthy findings include 1) the giant hail occurred outside the main precipitation core, in areas with low-altitude reflectivities of $40-50 \mathrm{dBZ}$; 2 ) the giant hail was associated with dual-polarization signatures consistent with past observations of large hail at $10-\mathrm{cm}$ wavelength, namely, low $Z_{\mathrm{DR}}$, low $\rho_{\mathrm{HV}}$, and low $K_{\mathrm{DP}} ; 3$ ) the giant hail fell along both the northeast and southwest edges of the primary updraft at ranges of $6-10 \mathrm{~km}$ from the updraft center; and 4) with the exception of one isolated report, the giant hail fell to the northeast and northwest of the large tornado and the parent mesocyclone.
\end{abstract}

\section{Introduction}

On 31 May 2013, an outbreak of severe thunderstorms occurred across central Oklahoma, producing several tornadoes, including one that resulted in fatalities, as well as flash flooding that led to additional fatalities (National Weather Service 2014). One storm from the outbreak, the El Reno Storm, has been well studied. Several papers have discussed aspects of the storm's record-width tornado (Snyder and Bluestein 2014; Bluestein et al. 2015; Kuster et al. 2015; Tanamachi and Heinselman 2016; Wakimoto et al. 2016; Bluestein et al. 2018) and the unfortunate deaths of three severe storm researchers (Wurman et al. 2014). However, until now, a comprehensive examination of the giant hail (defined in this paper as being $>7 \mathrm{~cm}$ in diameter) produced by the El Reno Storm has not been documented [although some preliminary analysis has been previously

Corresponding author: Arthur Witt, arthur.witt@noaa.gov presented by Witt (2014), Witt et al. (2015), and Seimon et al. (2016)]. As will be shown, verified and measured hailstones with diameters as large as $16 \mathrm{~cm}$ (6.3 in) fell in and near El Reno. The documentation of hailstones of that diameter is rare, with only a few verified instances of hail that large or larger (Blair and Leighton 2012; Pojorlie et al. 2013; Blair et al. 2017). Even so, most hailrelated deaths and injuries worldwide are from hail larger than $10 \mathrm{~cm}$ in diameter (Thuras 2010). Although greater hail damage may result from larger concentrations (i.e., number of hailstones per square meter) of smaller, but still large hail $(>4 \mathrm{~cm}$ in diameter; e.g., Changnon and Burroughs 2003; Changnon 2009), giant hailstones are often responsible for the most spectacular damage, given their ability to penetrate vehicle windshields and occasionally the roofs of houses and other structures.

The giant hail from the El Reno Storm fell within $60-\mathrm{km}$ range of several central-Oklahoma radars, including two fixed-site research radars in Norman, the National Weather Radar Testbed Phased Array Radar (NWRT 
PAR, hereafter PAR; Zrnić et al. 2007) and KOUN, the NEXRAD, long-term research WSR-88D. In the spring of 2013, KOUN was upgraded to dual-polarization (DP) capability and modified to perform sector scans (Tanamachi and Heinselman 2016). This provided the opportunity to compare and analyze rapid-scan full volumes from PAR (without DP) and rapid-scan partial volumes from KOUN (with DP). On 31 May, both the PAR and KOUN collected full and partial volume scans (respectively) of $\sim 1.5$-min duration during periods of giant hailfall, providing excellent temporal resolution for tracking hail signatures. In addition, one rapidscanning X-band polarimetric ( $\mathrm{RaXPol})$ mobile radar observed the storm from close range and provided data for a portion of the giant hailfall time. Information about RaXPol can be found in Pazmany et al. (2013).

Officially, the NCEI storm data (National Centers for Environmental Information 2013) contain only one report of giant hail from the El Reno Storm, and details of amount, location, and time are not well documented. When strong and violent tornadoes are in progress, it is not unusual for severe hail reports to not be made or to be missed by National Weather Service (NWS) storm reporting (Kelly et al. 1985; Allen and Tippett 2015). Most of the hail reports used in this analysis were collected with crowd-sourcing techniques that were not completed until a year or more after the storm (see section 2). The analysis of giant hailfall in this paper only applies to the area near the tornado where large numbers of storm chasers gathered (from $\sim 20 \mathrm{~km}$ westsouthwest of El Reno to $\sim 10 \mathrm{~km}$ east of El Reno). Since the El Reno Storm was strong over a relatively long track (from near Hinton to the eastern portions of Oklahoma City), it is possible that giant hail may have fallen, but not have been reported, in a longer swath than what is documented in this study [see Blair et al. (2017) for a detailed study of this problem].

The primary focus of this paper is on the radar observations of the El Reno Storm from its initial development through when it produced giant hail up to $16 \mathrm{~cm}$ in diameter. Data and methods are discussed in section 2, with section 3 detailing the observations of the storm from the PAR. Section 4 presents DP data from KOUN and RaxPol around the time periods of giant hail. Discussion and conclusions follow in sections 5 and 6.

\section{Data and methods}

\section{a. Giant hailstone observations}

Observations of giant hail mostly were obtained from the El Reno Survey Project (ERSP; Seimon et al. 2016). The project used social media sources and volunteered observations to collect many videos and photographs of the El Reno tornado, and by happenstance, giant hail, as recorded by those who were observing and chasing the storm. Using innovative techniques to match timed lightning/thunder observations to those found on video, it was possible to assign accurate times to all videos. Timing of hail observations came from several sources: some from accompanying video times, some from observer comments and digital photos, some from the times of nearby reports, and three were estimates using radar data. These data form the basis of the giant hail dataset, but other data were collected from NSSL sources, including contact with employees and friends of employees who witnessed the storm. In all, 13 different giant-hail data sources were obtained (Table 1). Because one fixed-location respondent took video of giant hail falling for $5 \mathrm{~min}$, time-to-space conversion of each minute of observation resulted in a total of 17 giant hail data points. Examples of a 16-cm hailstone (source 2 in Table 1) and a 13-cm hailstone (source 1 in Table 1) are shown in Fig. 1. An example of a 13-cm hailstone penetrating the roof of a house and ending up in the attic (source 5 in Table 1) is shown in Fig. 2. All three stones fell in the western portion of the town of El Reno, and, as with most giant hailfalls, coverage of the giant hailstones was sparse, with spacing $>5 \mathrm{~m}$ between stones (Browning 1977). The concurrent fall of small hail was not recorded for any of the reports.

The locations of the 13 giant-hail sources, with respect to the tornado path, are shown in Fig. 3. Times for sources $1-5$ are early in the tornado lifetime, and the locations are well northeast of the tornado position. For analysis purposes, these sources will be called the forward-flank giant hailfall (FFGH; 2304-2309 UTC). Source 7 may also be related to the FFGH, but the report location and time are different enough to not be included in the grouping. Times for sources $8-13$ are later in the tornado lifetime, and locations are northwest of the tornado position. For analysis purposes, these sources will be called the rear-flank giant hailfall (RFGH; 2319-2324 UTC). Source 6 is unique; its location is within the tornado damage path, the time of hailfall is during tornado passage, and the observer of this stone said it fell as he was being buffeted by tornado debris south of the center of the tornado. Source 6 is readdressed in section 5 .

\section{b. Radars}

The two fixed-site research radars (PAR, KOUN) are located on adjacent plots on the University of Oklahoma North Base, within the northwest portion of Norman, Oklahoma (Fig. 4). RaXPol deployed several times on a mission to collect wind and polarimetric data at low 

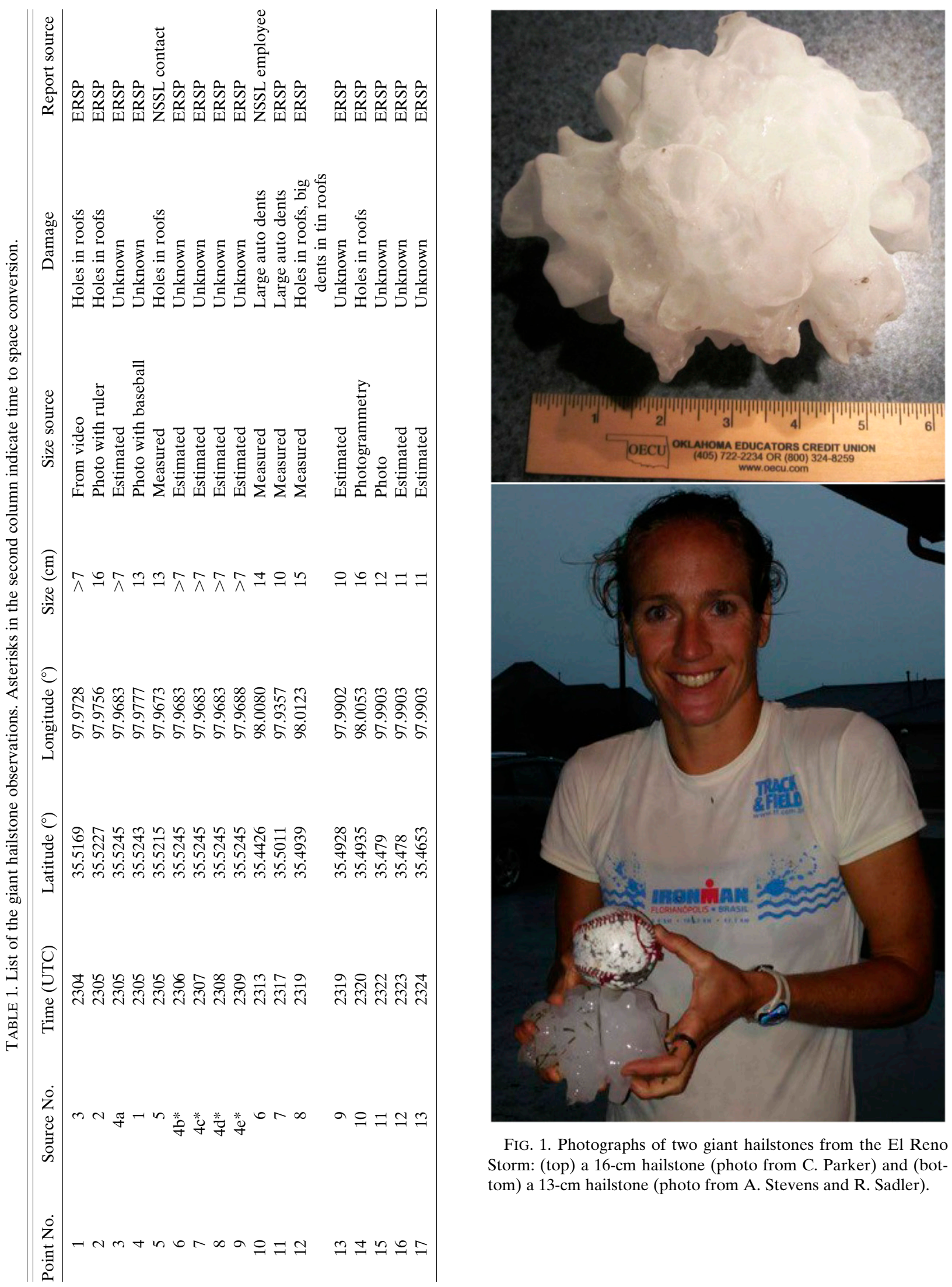

FIG. 1. Photographs of two giant hailstones from the El Reno Storm: (top) a 16-cm hailstone (photo from C. Parker) and (bottom) a 13-cm hailstone (photo from A. Stevens and R. Sadler). 


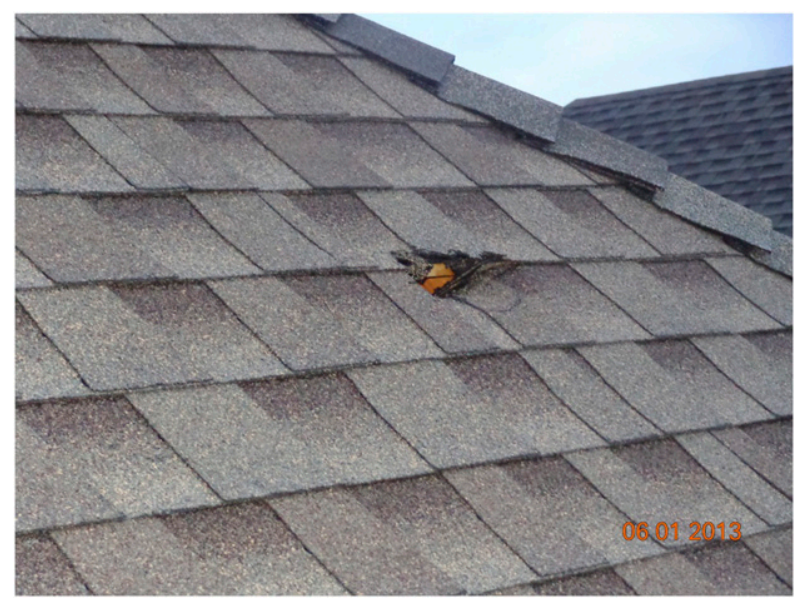

FIG. 2. Photograph of a hole in the roof of a house impacted by a $13-\mathrm{cm}$ hailstone (photo taken by D. Meyer; used with permission).

altitudes within the tornado (Snyder and Bluestein 2014), with close approach of the tornado necessitating several changes of location [see Bluestein et al. (2015) for information on the RaXPol data collection parameters on 31 May 2013]. One of the deployments occurred near one of the giant hailfall areas (location shown in Fig. 4). Because of its proximity to the storm and unique sampling characteristics, the spatiotemporal resolution of RaXPol data were significantly higher than those of the PAR and KOUN. To partially compensate for that difference, RaXPol data, except for reflectivity, were filtered (using the mean value from a window of 3 radials $\times 7$ range gates), resulting in $90 \mathrm{~m} \times 210 \mathrm{~m}$ spatial resolution. Also note that S- and X-band radars have different backscattering cross sections and can be in different scattering regimes for particles of similar size and type. Therefore, there may be differences in radar parameter values when sampling the same precipitation distribution (Fabry 2015). Although $X$-band $Z_{\mathrm{DR}}$ in hail regions may not always be as low as it tends to be at $\mathrm{S}$ band, the copolar correlation coefficient $\rho_{\mathrm{HV}}$ at X band may be more sensitive to hail than it is at S band (Snyder et al. 2010, 2017).

For the PAR data time period analyzed in this study (2119-2356 UTC), the radar scanned the El Reno Storm using the strategy in Table 2. To minimize update times, the PAR utilized a weather-focused adaptive scanning strategy (Heinselman and Torres 2011; Torres et al. 2016), whereby only areas of significant reflectivity return were scanned. Hence, early in the time period, as the storm was initially developing and strengthening, and more distant from the PAR, volume update time was as short as $\sim 0.5 \mathrm{~min}$, with fewer radials and elevation angles needed to scan the entire storm. As the storm became larger and taller, and moved closer to the radar, volume update time increased to as much as $2 \mathrm{~min}$ at the end of the period, as more radials and elevation angles were needed in each volume scan (along with delays due to more frequent adjustments to the scanning sector).

Storm characteristics and intensity were assessed via five radar parameters. The two velocity-based parameters

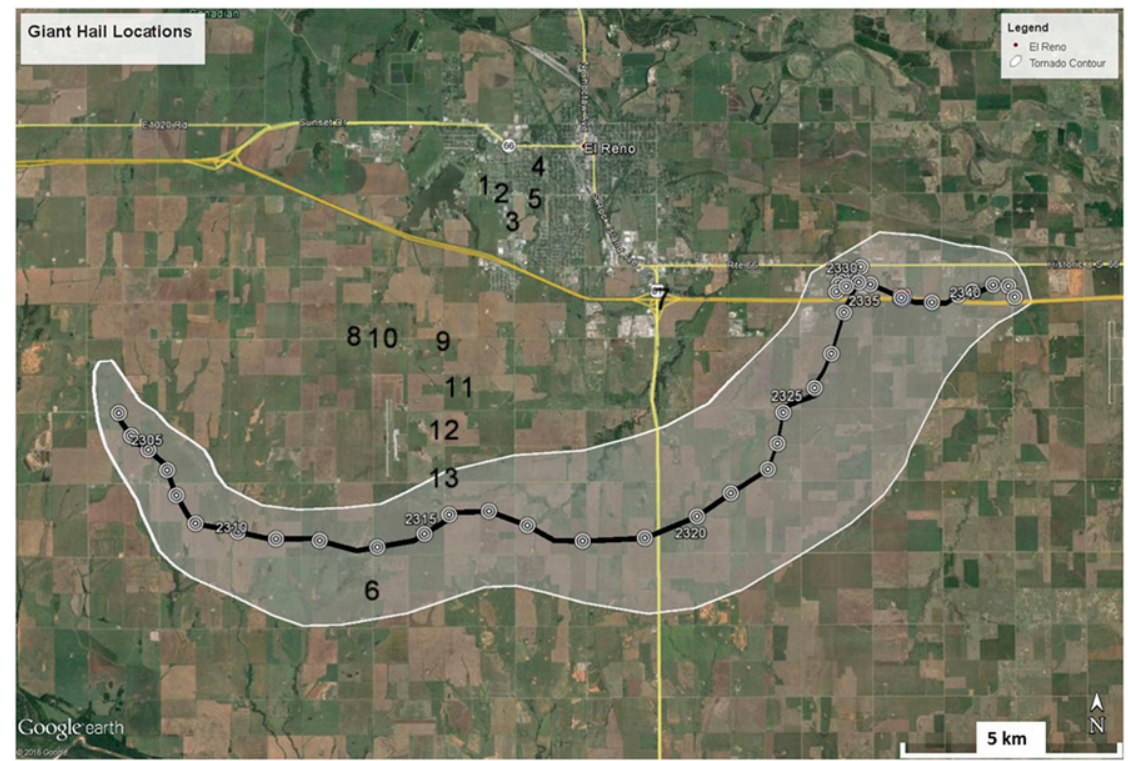

FIG. 3. Locations of the 13 giant-hail sources (black numerals) with respect to the tornado path. Sources 1-5 correspond to the FFGH and sources 8-13 correspond to the RFGH. The tornado track was determined from the damage survey completed by the NWS Forecast Office in Norman, OK. 


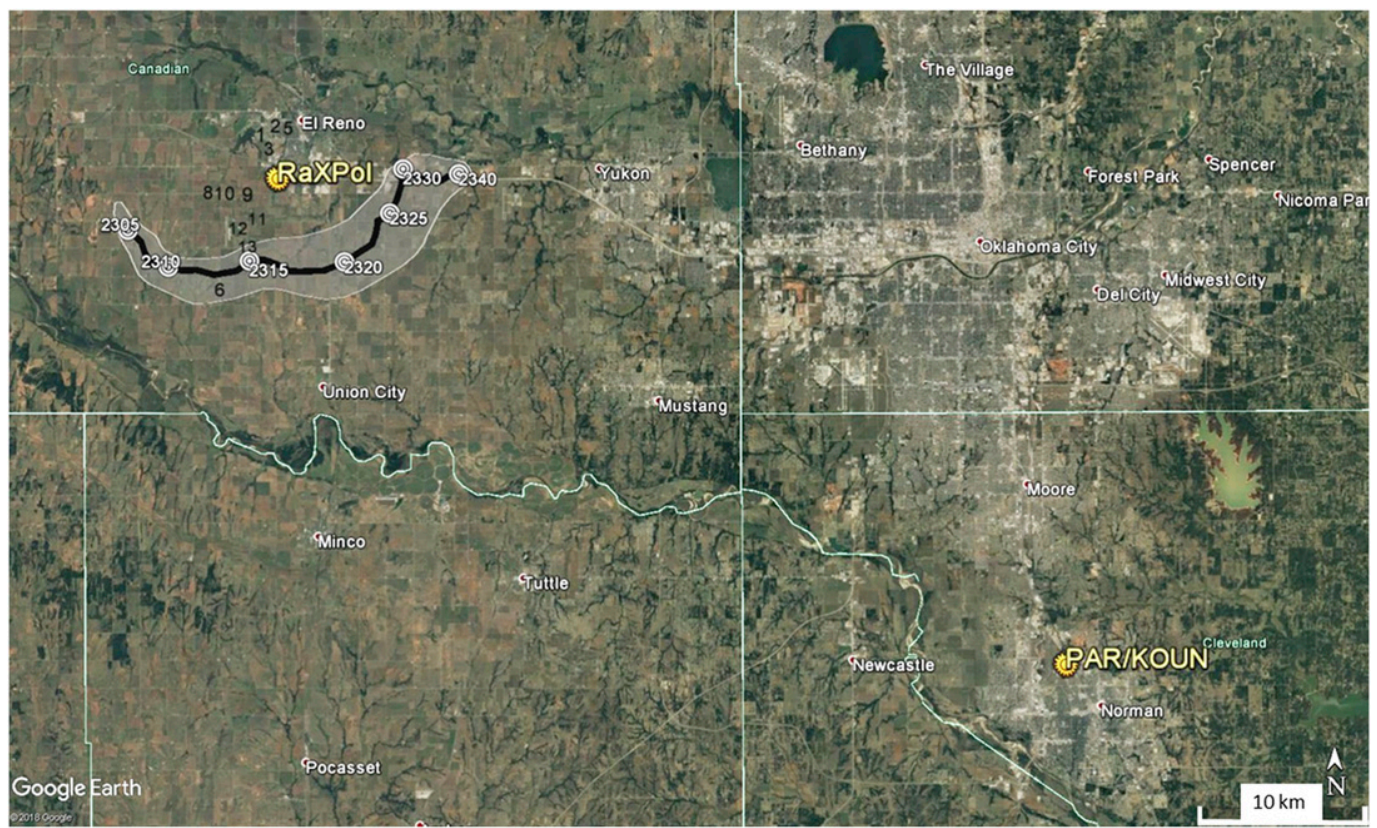

FIG. 4. Location of the PAR and KOUN radars (circular symbol in the lower right) and the RaXPol radar (circular symbol in the upper left). The tornado damage path and giant hail sources are marked as in Fig. 3 .

were derived from the radial velocity data, with the three reflectivity parameters determined after mapping the radial reflectivity data to a $3 \mathrm{D}$ latitude-longitudeheight grid at a resolution of $0.01^{\circ} \times 0.01^{\circ} \times 1.0 \mathrm{~km}$ (Lakshmanan et al. 2006). The reflectivity-based parameters examined were 1) maximum reflectivity at the $-20^{\circ} \mathrm{C}$ environmental temperature height $Z_{253 \mathrm{~K}}$, 2) vertically integrated liquid water content (VIL; Amburn and Wolf 1997), and 3) maximum expected size of hail (MESH; Witt et al. 1998; Lakshmanan et al. 2007). The choice of $Z_{253 \mathrm{~K}}$, versus reflectivity at a different temperature height, was based on the $-20^{\circ} \mathrm{C}$ height being an important temperature for the growth of large hail (Nelson 1983), with the temperature heights used in this study coming from the near-storm environment (NSE) algorithm (Lakshmanan et al. 2007). The velocity-based parameters examined were 1) maximum storm-top divergent outflow (STD; Witt and Nelson 1991) and 2) maximum midaltitude rotational velocity (MRV; Witt 1998), with midaltitude being 3-11 km above radar level (ARL). The equations for STD and MRV are

$$
\begin{aligned}
\mathrm{STD} & =V_{D \max }-V_{D \min } \quad \text { and } \\
\mathrm{MRV} & =\left(V_{R \max }-V_{R \min }\right) / 2,
\end{aligned}
$$

where $V_{D \min }$ and $V_{D \max }$ are the peak inbound and outbound velocities in the storm-top divergent signature, and $V_{R \min }$ and $V_{R \max }$ are the peak inbound and outbound velocities in the midaltitude rotation signature within the storm. To focus the calculation of MRV on rotation versus divergence, the line connecting the locations of $V_{R \min }$ and $V_{R \max }$ needed to be more perpendicular than parallel to the radar viewing direction [i.e., have an angle $>45^{\circ}$; see section 4.7 in Brown and Wood (2007)]. To minimize errors in the calculation of STD and MRV, only manually dealiased radial velocity data with corresponding reflectivity $\geq 15 \mathrm{dBZ}$ and spectrum width $<13 \mathrm{~m} \mathrm{~s}^{-1}$ were used (these thresholds were subjectively chosen based on the experience of A. Witt and D. Burgess). To avoid use of unreliable data, an additional criterion was that a candidate velocity have sufficient spatial continuity with neighboring velocities on the same elevation scan, defined here as at least one adjacent velocity value within $5 \mathrm{~m} \mathrm{~s}^{-1}$ of the candidate velocity value. In the calculation of STD, to reduce the altitude difference between $\mathrm{V}_{D \text { min }}$ and $\mathrm{V}_{D \text { max }}, \mathrm{V}_{D \text { min }}$ could come from either the same or higher elevation scans as $\mathrm{V}_{D \text { max }}$. Parameter $\mathrm{V}_{D \text { min }}$ at higher elevation scans (than $\mathrm{V}_{D \max }$ ) was primarily used to minimize the

TABLE 2. PAR scanning strategy.

\begin{tabular}{lc}
\hline \hline Sector width & $90^{\circ}$ \\
Elevation angles & $0.51^{\circ}, 0.9^{\circ}, 1.3^{\circ}, 1.8^{\circ}, 2.4^{\circ}, 3.1^{\circ}, 4.0^{\circ}, 5.1^{\circ}$, \\
& $6.4^{\circ}, 8.0^{\circ}, 10.0^{\circ}, 12.5^{\circ}, 15.6^{\circ}, 19.5^{\circ}, 23.37^{\circ}$, \\
Update time & $28.2^{\circ}, 34.25^{\circ}, 42.8^{\circ}, 52.9^{\circ}$ \\
Azimuthal sampling & $25-111 \mathrm{~s}$ \\
Radial resolution & $0.75^{\circ}$ \\
Nyquist velocity & $240 \mathrm{~m}$ \\
\hline
\end{tabular}


TABLE 3. KOUN scanning strategy.

\begin{tabular}{lc}
\hline \hline Sector width & $90^{\circ}-105^{\circ}$ \\
Elevation angles & $0.52^{\circ}, 0.97^{\circ}, 1.5^{\circ}, 2.05^{\circ}, 3.05^{\circ}, 4.05^{\circ}, 5.05^{\circ}$, \\
& $5.95^{\circ}, 7.97^{\circ}, 9.9^{\circ}$ \\
Update time & $98-100 \mathrm{~s}$ \\
Azimuthal sampling & $0.5^{\circ}$ \\
Radial resolution & $250 \mathrm{~m}$ \\
Maximum range & $124 \mathrm{~km}$ \\
Nyquist velocity & $33.2 \mathrm{~m} \mathrm{~s}^{-1}$ \\
\hline
\end{tabular}

height difference between it and $V_{D \max }$ (so that the STD calculation was as close as possible to measuring horizontal divergence).

For the time period analyzed in this study (22282334 UTC), the KOUN radar scanned using the strategy in Table 3. During the entire time of the analysis, to limit the volume scan time to $\sim 1.5 \mathrm{~min}$, the highest elevation angle in the volume scan was $9.9^{\circ}$. Hence, the upper parts of the storm were not scanned. Thus, the KOUN data were primarily used to examine the low to midaltitude evolution of several DP parameters during the FFGH and RFGH, including reflectivity $Z, Z_{\mathrm{DR}}, \rho_{\mathrm{HV}}$, and specific differential phase $K_{\mathrm{DP}}$ [see Kumjian (2013) for a description of, and more information about, polarimetric radar variables]. For each DP variable, its value at the FFGH and RFGH was calculated from the median of the eight radar gates within a $1^{\circ} \times 1 \mathrm{~km}$ window centered on the FFGH and RFGH for the lowest three elevation scans [similar to the procedure in two previous studies (Picca and Ryzhkov 2012; Blair et al. 2012) analyzing DP observations associated with giant hail]. Also examined were vertical and horizontal cross sections of these fields during the giant hailfalls. The vertical cross sections were along the radial passing through the location of the giant hailfalls, and the horizontal cross sections were at 5-km ARL. The choice of 5-km ARL for the horizontal cross sections was based on this being approximately the midpoint
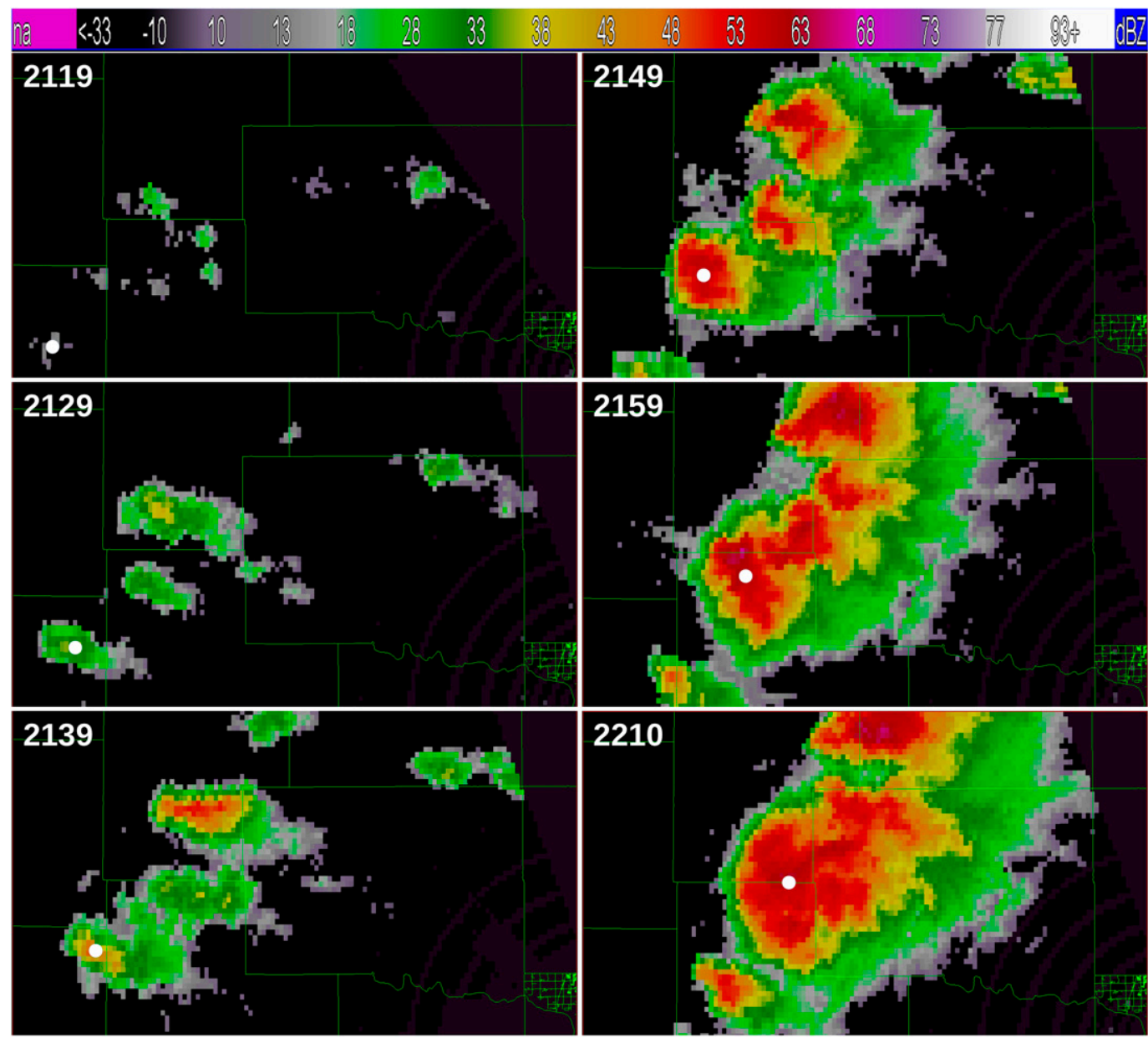

FIG. 5. PAR reflectivity at the $-20^{\circ} \mathrm{C}$ height from first echo at 2119 to 2210 UTC at $\sim 10$-min intervals. White dots indicate the El Reno Storm, with the image time in the top-left corner. 


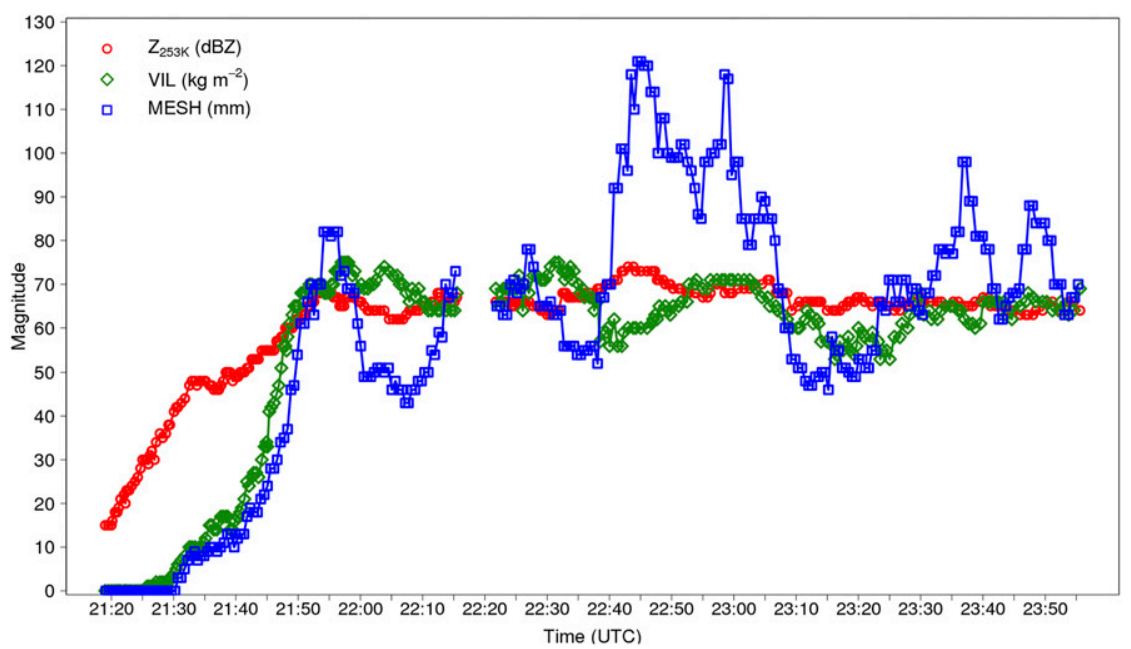

FIG. 6. Time series of PAR-derived $Z_{253 \mathrm{~K}}$ (red), VIL (green), and MESH (blue) from 2119 to 2356 UTC for the El Reno Storm. There is a 6-min gap in PAR scanning from 2216 to 2221 UTC.

(vertically) of the $Z_{\mathrm{DR}}$ and $\rho_{\mathrm{HV}}$ columns (see section 4 for details).

\section{PAR observations of storm evolution}

a. Initial rapid-growth phase: 2119-2159 UTC

The first PAR echo of the El Reno Storm was at 2119 UTC (Fig. 5). Given an environment supportive of explosive thunderstorm growth [surface-based convective available potential energy $>5000 \mathrm{~J} \mathrm{~kg}^{-1}$; see Bluestein et al. (2015), Kuster et al. (2015), and Witt
(2014) for soundings and other information on the storm environment], the storm rapidly intensified, quickly becoming a supercell (Doswell and Burgess 1993). The $Z_{253 \mathrm{~K}}$ increased from $15 \mathrm{~dB} Z$ at 2119 UTC to $69 \mathrm{~dB} Z$ at 2154 UTC (Fig. 6). VIL and MESH also increased rapidly, particularly between 2140 and 2159 UTC, reaching as high as $74 \mathrm{~kg} \mathrm{~m}^{-2}$ and $8.2 \mathrm{~cm}$, respectively. As for the velocity parameters, STD followed a pattern similar to the reflectivity parameters, increasing from $18 \mathrm{~m} \mathrm{~s}^{-1}$ at 2127 UTC to $105 \mathrm{~m} \mathrm{~s}^{-1}$ at 2159 UTC (Fig. 7). The mesocyclone MRV, first

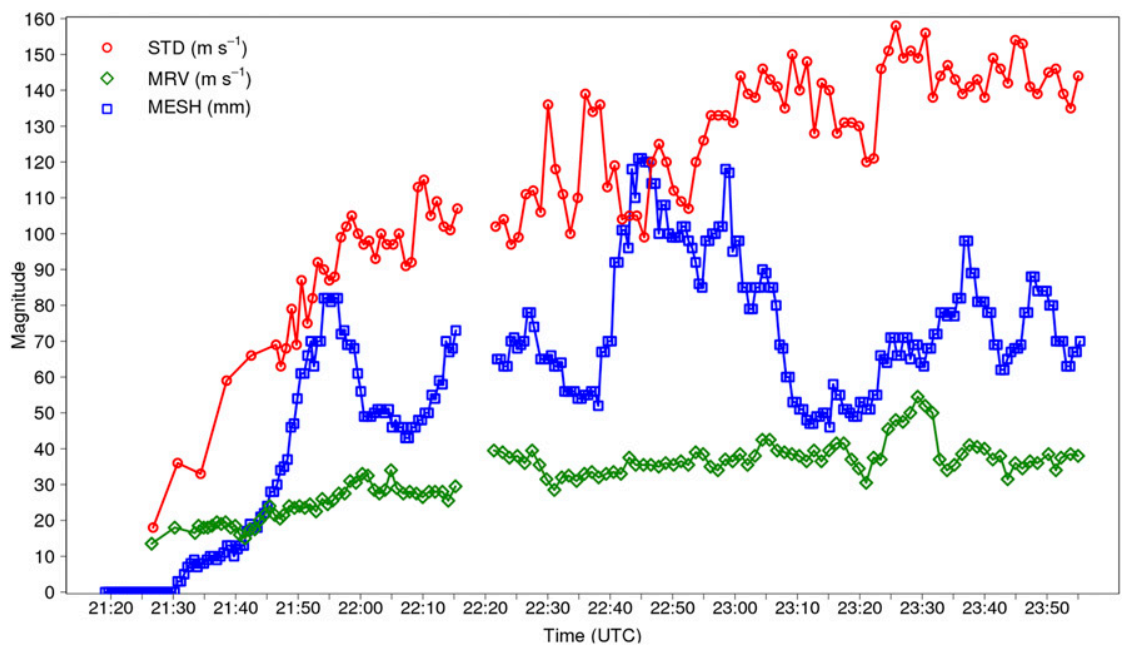

FIG. 7. Time series of PAR-derived STD (red), MRV (green), and MESH (blue) for the El Reno Storm from 2119 to 2356 UTC, except for the first five measurements of STD (from 2127 to 2143 UTC) and first two measurements of MRV (from 2127 to 2131 UTC), which were obtained from the KTLX WSR-88D due to range-folding of the PAR velocity data. There is a 6-min gap in PAR scanning from 2216 to 2221 UTC. 

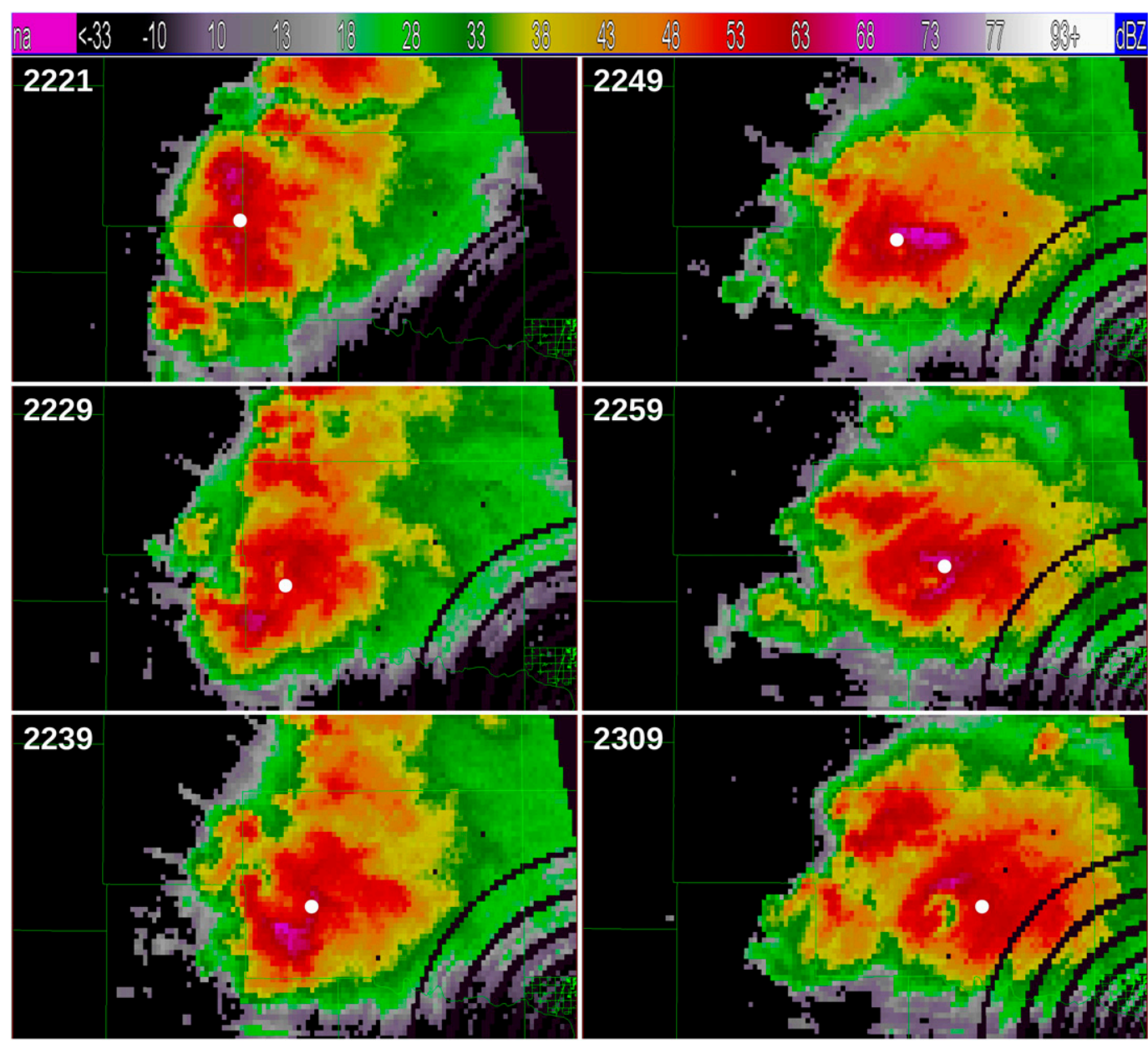

FIG. 8. PAR reflectivity at the $-20^{\circ} \mathrm{C}$ height from 2221 to 2309 UTC at $\sim 10$-min intervals. White dots indicate the El Reno Storm, with the image time in the top-left corner.

detected at 2126 UTC, increased from 13 to $31 \mathrm{~m} \mathrm{~s}^{-1}$ by 2159 UTC.

\section{b. Quasi-steady supercell phase: 2200-2238 UTC}

Following the initial period of rapid growth, the El Reno Storm continued to increase in both size and intensity, but at a slower rate. The growth was due to both expansion of the main storm and mergers with surrounding weaker storms. However, storm intensity, as measured by the radar parameters examined, exhibited only minor fluctuations during this period: $Z_{253 \mathrm{~K}}$ varied between 62 and $69 \mathrm{~dB} Z$, VIL varied between 65 and $75 \mathrm{~kg} \mathrm{~m}^{-2}$, and MESH varied between 4.3 and $7.8 \mathrm{~cm}$ (Fig. 6). During the quasi-steady period, velocity parameters also exhibited similar minor oscillations, with STD edging upward to near $140 \mathrm{~m} \mathrm{~s}^{-1}$ by the end of the period (Fig. 7). During both the rapid-growth and quasi-steady phases, the storm was in mostly rural areas, and observed by a large number of storm chasers (Seimon et al. 2016).
Only one severe hail report was received during the entire 2119-2238 UTC interval: $3.8-\mathrm{cm}$ hail reported just southeast of Hinton (west of El Reno) at 2220 UTC.

\section{c. Classic/high-precipitation supercell phase: 2239-2356 UTC}

At $\sim 2230$ UTC, the El Reno Storm merged with another strong cell that approached from the southwest (see Fig. 8). Although the storm quickly became a supercell after first echo, following the cell merger (at 2230 UTC), the El Reno Storm underwent another distinct intensification phase during which it transitioned initially into a "classic" supercell (Rasmussen and Straka 1998), displaying a distinct hook echo (Fig. 9), deep bounded weak echo region (BWER; Fig. 10), strong mesocyclone, tornadic vortex signature (TVS), and tornado debris signature (TDS; Fig. 11). The El Reno Storm then evolved into more of a high-precipitation (HP) supercell following tornado development at 2303 UTC, with a 


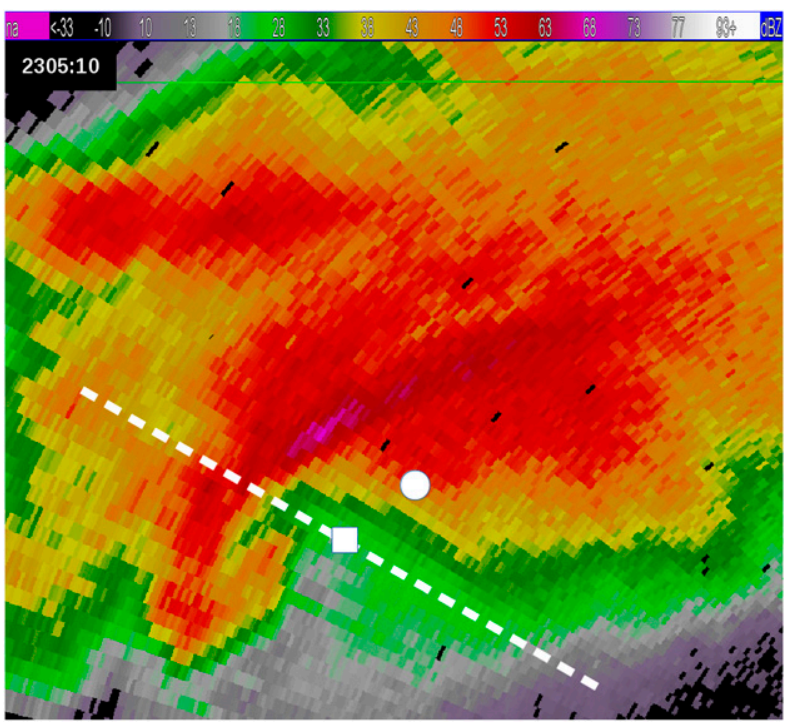

FIG. 9. PAR $0.5^{\circ}$ reflectivity scan at $2305: 10$ UTC. The dashed line shows location of the vertical cross section in Fig. 10a with the white square at the midpoint of the cross section (reference the square in Fig. 10a). The white circle shows the location of the FFGH.

significant amount of precipitation falling around the rear flank of the storm. In the early part of this intensification phase, there was a large, rapid increase in $\mathrm{MESH}$, from $5.2 \mathrm{~cm}$ at $2238 \mathrm{UTC}$ to $12.1 \mathrm{~cm}$ at 2245 UTC, and a second peak of $11.8 \mathrm{~cm}$ at 2259 UTC (Fig. 6). During most of the period of observed giant hailfall (2304-2324 UTC), MESH decreased, falling to as low as $4.6 \mathrm{~cm}$ at 2315 UTC. MESH increased afterward, reaching peaks of $9.8 \mathrm{~cm}$ at 2338 UTC and $8.8 \mathrm{~cm}$ at 2347 UTC. The NCEI storm data contain a report of giant hail (15-cm diameter) in El Reno at 2305 UTC, but a location is not given. It is likely that the report is the same as one of the giant hail sources that appear in Table 1. The NCEI storm data contain two other El Reno Storm severe hail reports during the classic/HP supercell phase: $2.5-\mathrm{cm}$ hail in Warr Acres (western Oklahoma City) at 2339 UTC and 4.6-cm hail in Yukon (just west of Oklahoma City) at 2355 UTC.

As the classic/HP supercell phase began, a broad increase in STD occurred, beginning at $\sim 2240$ UTC and reaching peaks at $2310 \mathrm{UTC}\left(150 \mathrm{~m} \mathrm{~s}^{-1}\right)$ and $2326 \mathrm{UTC}$ $\left(158 \mathrm{~m} \mathrm{~s}^{-1}\right.$; Fig. 7$)$. The broad time period of STD > $135 \mathrm{~m} \mathrm{~s}^{-1}$ undoubtedly is related to the sustained extreme updraft associated with the El Reno Storm during the strong tornado (2303-2344 UTC). The midaltitude mesocyclone, already strong during the latter part of the quasi-steady supercell phase, continued to increase in rotational velocity during the classic/HP supercell phase, with MRV reaching a peak of $54.5 \mathrm{~m} \mathrm{~s}^{-1}$ at 2330 UTC (around the same time as the maximum STD value). The

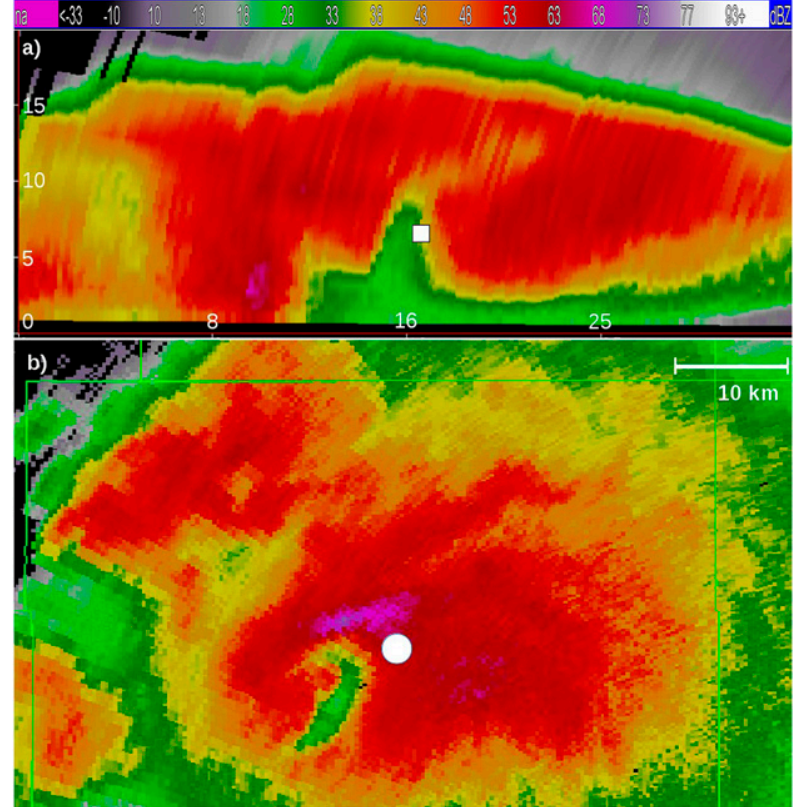

FIG. 10. PAR reflectivity (a) vertical cross section along the dashed line in Fig. 9 and (b) horizontal cross section at a height of $6 \mathrm{~km}$ ARL. Horizontal distance and vertical height (shown via white numerals) in (a) are in kilometers. The white square in (a) corresponds to the location shown in Fig. 9. The white circle in (b) shows the location of the FFGH. The cross sections were derived from the PAR volume scan collected from 2305:10 to 2306: 17 UTC

low-altitude mesocyclone, which is more closely related to tornado occurrence and intensity than is the midaltitude mesocyclone (Markowski and Richardson 2014), reached a maximum rotational velocity of $64 \mathrm{~m} \mathrm{~s}^{-1}$, placing it in the top few percent of all tornadic mesocyclones (Smith et al. 2015).

\section{KOUN and RaXPol radar observations of giant hailfall}

Despite the $>2.5 \mathrm{~h}$ time period of PAR analysis that was used to describe storm evolution (section 3), the time period of analysis of giant hailfall is primarily limited to the times in Table 1 (2304-2324 UTC). This time restriction arises from the lack of hail reports from the storm apart from those gathered by the ERSP. Reasons for the lack of a longer interval of detailed hailfall analysis (including giant hail) were given toward the end of section 1 and include references to other authors who have encountered this problem.

\section{a. Forward-flank giant hailfall: 2304-2309 UTC}

Low-altitude KOUN reflectivity scans just before and during the FFGH (Fig. 12) reveal that its location is 


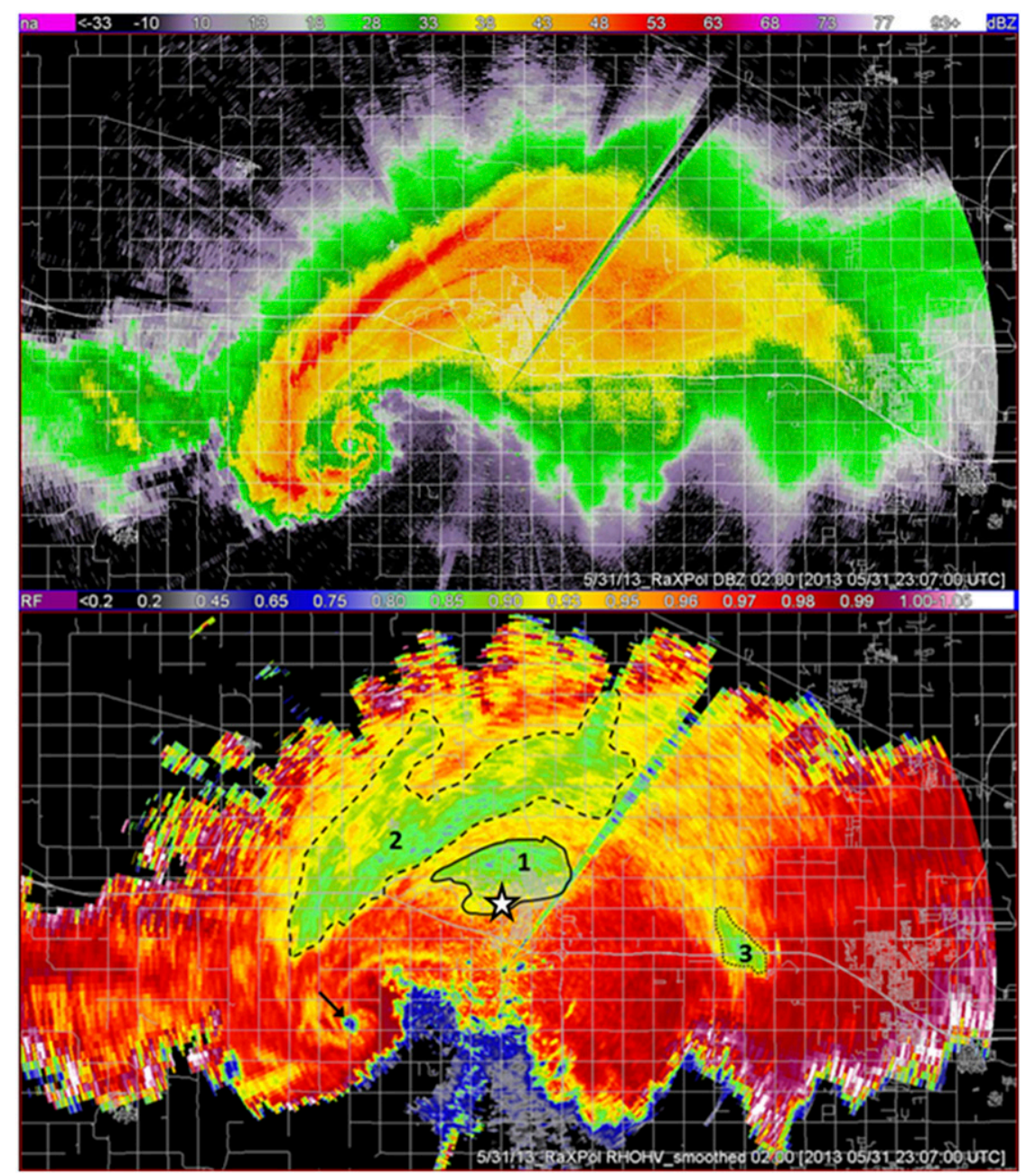

FIG. 11. Images from the $2^{\circ}$ elevation scan of (top) RaXPol reflectivity and (bottom) filtered copolar correlation coefficient at 2307 UTC. Regions 1-3 (marked in the bottom panel) are likely hail areas discussed in the text. Tornado debris signature marked with a dark arrow in the bottom panel. The star shows the location of the FFGH.

along the southern edge of the forward-flank echo, well south of the forward-flank core. At midaltitudes, the FFGH is below the leading edge of the reflectivity gradient defining the eastern wall of the BWER (Fig. 13a). With respect to $Z_{\mathrm{DR}}$ (Fig. 14), the FFGH location is at the northern edge of the low-altitude $Z_{\mathrm{DR}}$ arc [large $Z_{\mathrm{DR}}$ values; see Kumjian and Ryzhkov (2008) for more information on the $Z_{\mathrm{DR}}$ arc]. With time, the $Z_{\mathrm{DR}}$ values along the northern edge of the $Z_{\mathrm{DR}}$ arc decrease owing to the fall of giant hail. At midaltitudes (Fig. 13b), the FFGH location is just ahead of and at the leading edge of the $Z_{\mathrm{DR}}$ column (located at $\sim 12 \mathrm{~km}$ in Fig. 15b) thought to mark the location of at least a portion of the primary updraft (Snyder et al. 2015). The $\rho_{\mathrm{HV}}$ (Fig. 16) relationships to the FFGH location are much the same as the $Z_{\mathrm{DR}}$ relationships. Low-altitude $\rho_{\mathrm{HV}}$ values suggest the FFGH is at the leading edge of and within a larger area of reduced $\rho_{\mathrm{HV}}$ values, indicative of mixed precipitation types. At midaltitudes (Fig. 13c), the FFGH location is just ahead of and at the leading edge of the $\rho_{\mathrm{HV}}$ column (located at $\sim 12 \mathrm{~km}$ in Fig. $15 \mathrm{c}$ ). As with the $Z_{\mathrm{DR}}$ column, the $\rho_{\mathrm{HV}}$ column is thought to mark the location of at least a portion of the primary updraft.

Time series of low-altitude KOUN DP parameters above the FFGH reveal that low-altitude reflectivity decreases from forward-flank core values larger than $50 \mathrm{~dB} Z$ just before the FFGH to values as low as $41 \mathrm{dBZ}$ as the giant hailfall begins (Fig. 17). These reflectivity values are considerably less than the $55+\mathrm{dB} Z$ values often associated with severe hail (Witt 1996; Ryzhkov et al. 2013). After the FFGH, low-altitude reflectivities again increase, reaching maximum values $\sim 55 \mathrm{dBZ}$ as 


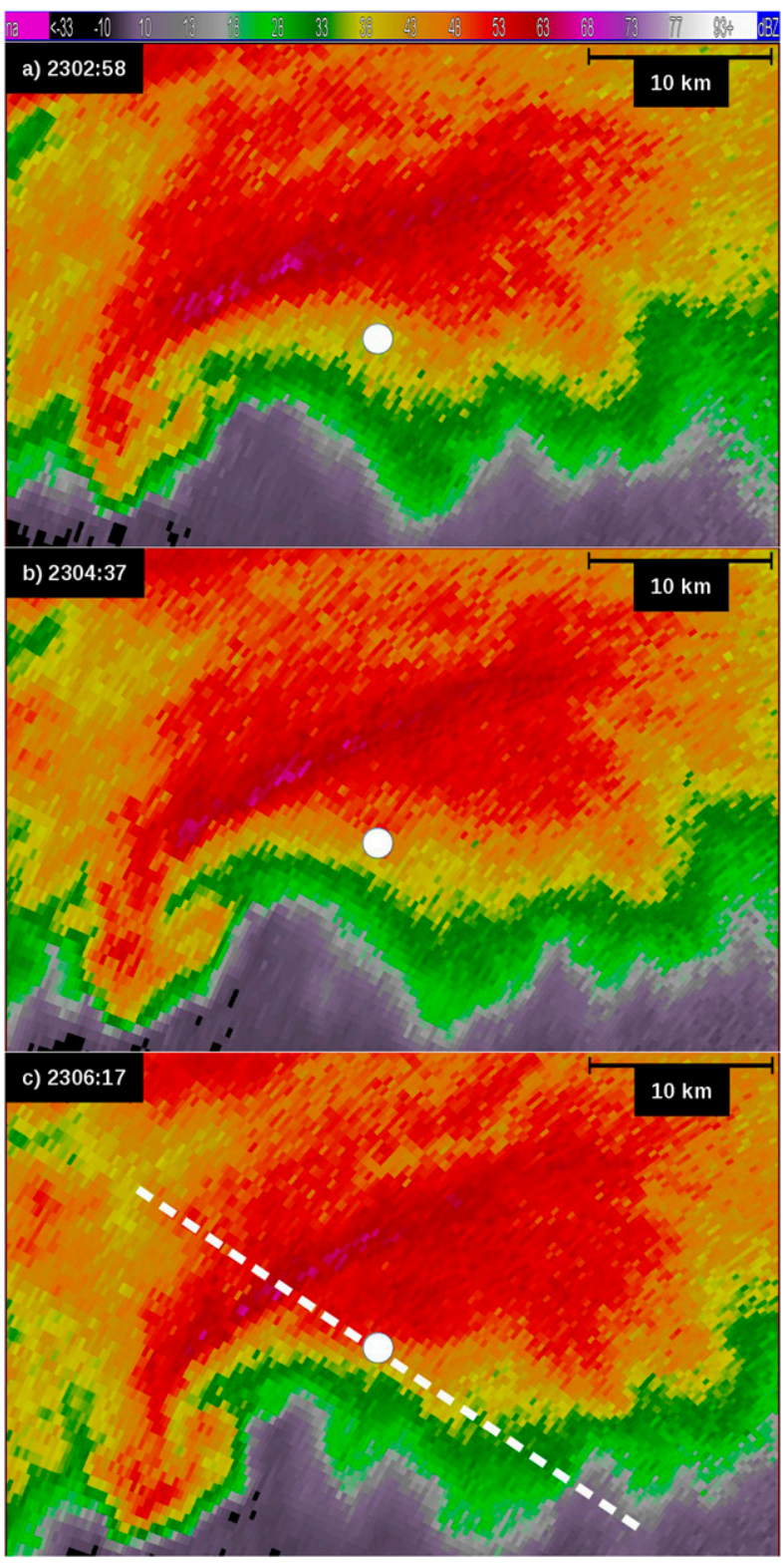

FIG. 12. KOUN $1^{\circ}$ reflectivity scans at (a) 2302:58, (b) 2304:37, and (c) 2306:17 UTC. The dashed line in (c) shows location of the vertical cross section in Fig. 15. The white circles show the location of the FFGH.

the southern portion of the rear-flank core passes. As the FFGH occurs, low-altitude $Z_{\mathrm{DR}}$ values drop precipitously from values associated with the $Z_{\mathrm{DR}}$ arc $(>5 \mathrm{~dB})$ to values often associated with the likely presence of hail $(\sim 1 \mathrm{~dB})$. The $Z_{\mathrm{DR}}$ values rise after the passage of the FFGH but fall again to values indicative of hail as the southern edge of the rear-flank core passes. Low-altitude $\rho_{\mathrm{HV}}$ is somewhat noisy but depicts 1$)$ high values $(\sim 0.99)$ in the forward-flank core; 2 ) decreasing values just before the FFGH; 3) the lowest values, indicative of hail, during
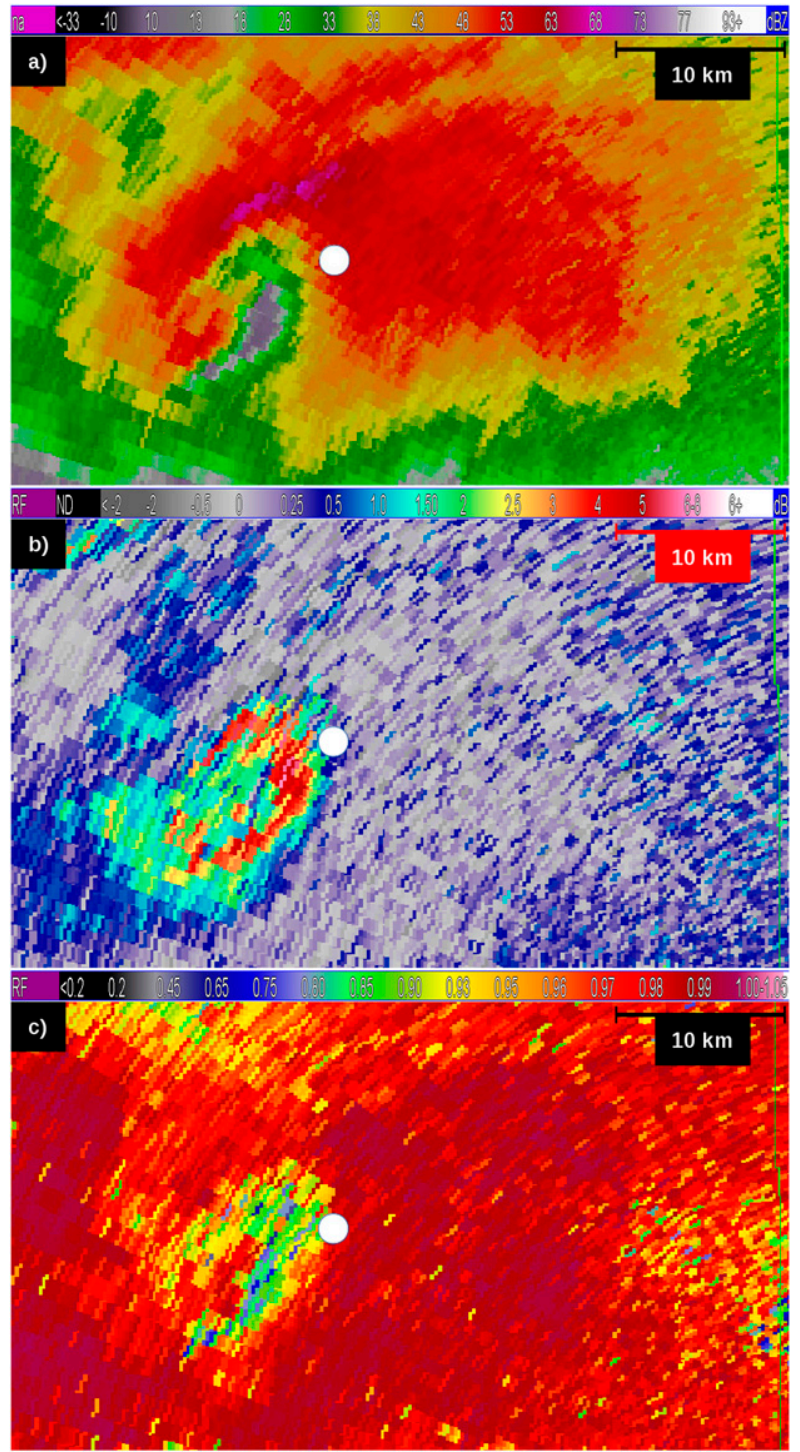

FIG. 13. KOUN horizontal cross sections at $5 \mathrm{~km}$ ARL of (a) reflectivity, (b) differential reflectivity, and (c) copolar correlation coefficient. The white circles show the location of the FFGH. The cross sections were derived from the KOUN volume scan collected from 2306:07 to 2307:43 UTC.

the FFGH; and 4) intermediate values ( $\sim 0.96)$, possibly indicative of hail, as the rear-flank core passes. Lowaltitude $K_{\mathrm{DP}}$ is between 0 and 1 before the FFGH, indicative of a time of generally light rain. During the FFGH, $K_{\mathrm{DP}}$ drops below 0 , suggesting that the light rain diminished or ended during the giant hailfall (confirmed by the hailfall videos), and that complex scattering of radar-beam energy by the giant hailstones might have occurred to produce the negative values (Smyth et al. 1999).

Whereas KOUN was scanning the area of the FFGH from a distance of $\sim 60 \mathrm{~km}$, RaXPol was at a position 


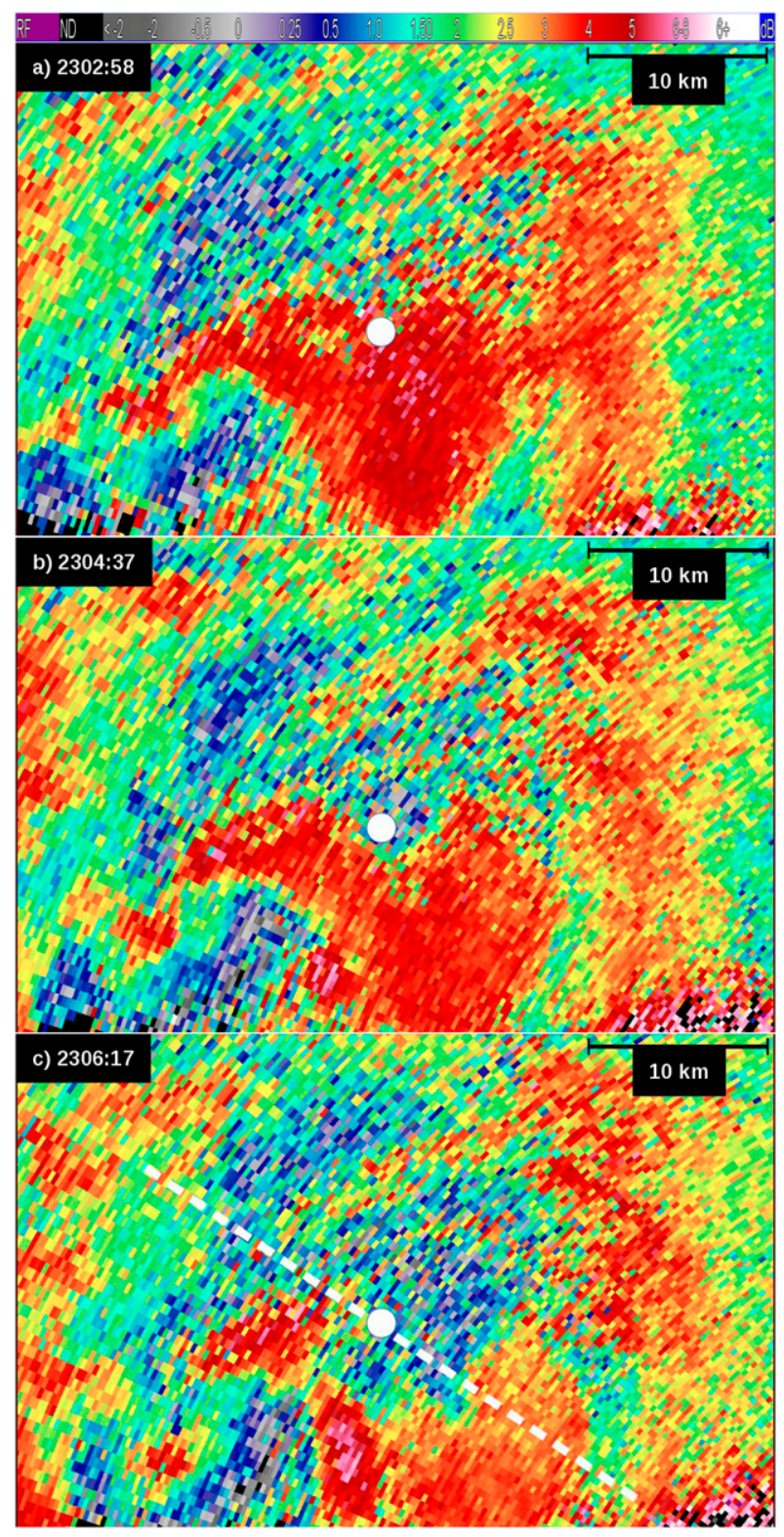

FIG. 14. As in Fig. 12, but for differential reflectivity.

along the leading edge of the forward flank of the supercell (Fig. 11). From that location, the FFGH was just 3-6 km to its north (shaded region outlined with a solid line and marked with "1" in Fig. 11). The X-band correlation coefficients within region $1(0.8-0.9)$ are somewhat comparable to the KOUN S-band values $(\sim 0.9)$ and help confirm the radar detection of hail there (Snyder et al. 2017). The reported FFGH observations are all in the southern portion of region 1 (see the star in Fig. 11), the reasons for which are not completely understood. It could be that the giant hailfall area was larger, but no reports were received from the remainder

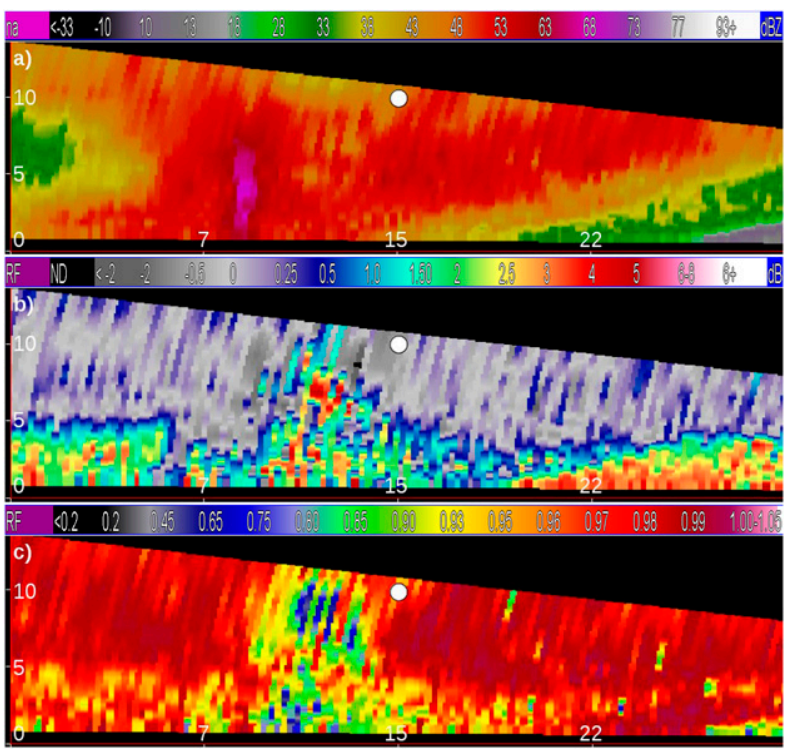

FIG. 15. KOUN vertical cross sections of (a) reflectivity, (b) differential reflectivity, and (c) copolar correlation coefficient. Horizontal distance and vertical height (shown via white numerals) are in kilometers. The white circles correspond to the location of the FFGH. The cross sections were derived from the KOUN volume scan collected from 2306:07 to 2307:43 UTC.

of the area. It also could be that scattering/resonance properties associated with the giant hail at $\mathrm{X}$ band (Kumjian et al. 2008) are extending the $\rho_{\mathrm{HV}}$ reduction farther down-radial than the extent of the giant hail. RaXPol data suggest a break between the FFGH area and a larger area of possible hail (shaded region outlined with a dashed line and marked with " 2 " in Fig. 11). This second area is more related to the traditional hail location within the rear-flank core. There is also a third area (shaded region outlined with a dotted line and marked with " 3 " in Fig. 11) on the right-front flank where $\rho_{\mathrm{HV}}$ values also suggest that hail or mixed precipitation types might have been present. The three hail areas are all north and northeast of the tornado location [indicated by the low $\rho_{\mathrm{HV}}$ tornado debris signature (Kumjian and Ryzhkov 2008); marked with a dark arrow on the bottom panel of Fig. 11].

\section{b. Rear-flank giant hailfall: 2319-2324 UTC}

The RFGH occurred at the back edge of the confluence of the hook echo and the rear-flank core (Fig. 18a). At low altitudes, the giant-hailfall location is $7-10 \mathrm{~km}$ northwest of the tornado (indicated via the TDS seen in Fig. 18c). At midaltitudes, the RFGH location is within the narrow western wall of high reflectivity that surrounds the BWER (Fig. 19a), with large portions of the BWER filled with mixed debris and precipitation lofted within the tornado circulation. At low altitudes, the 


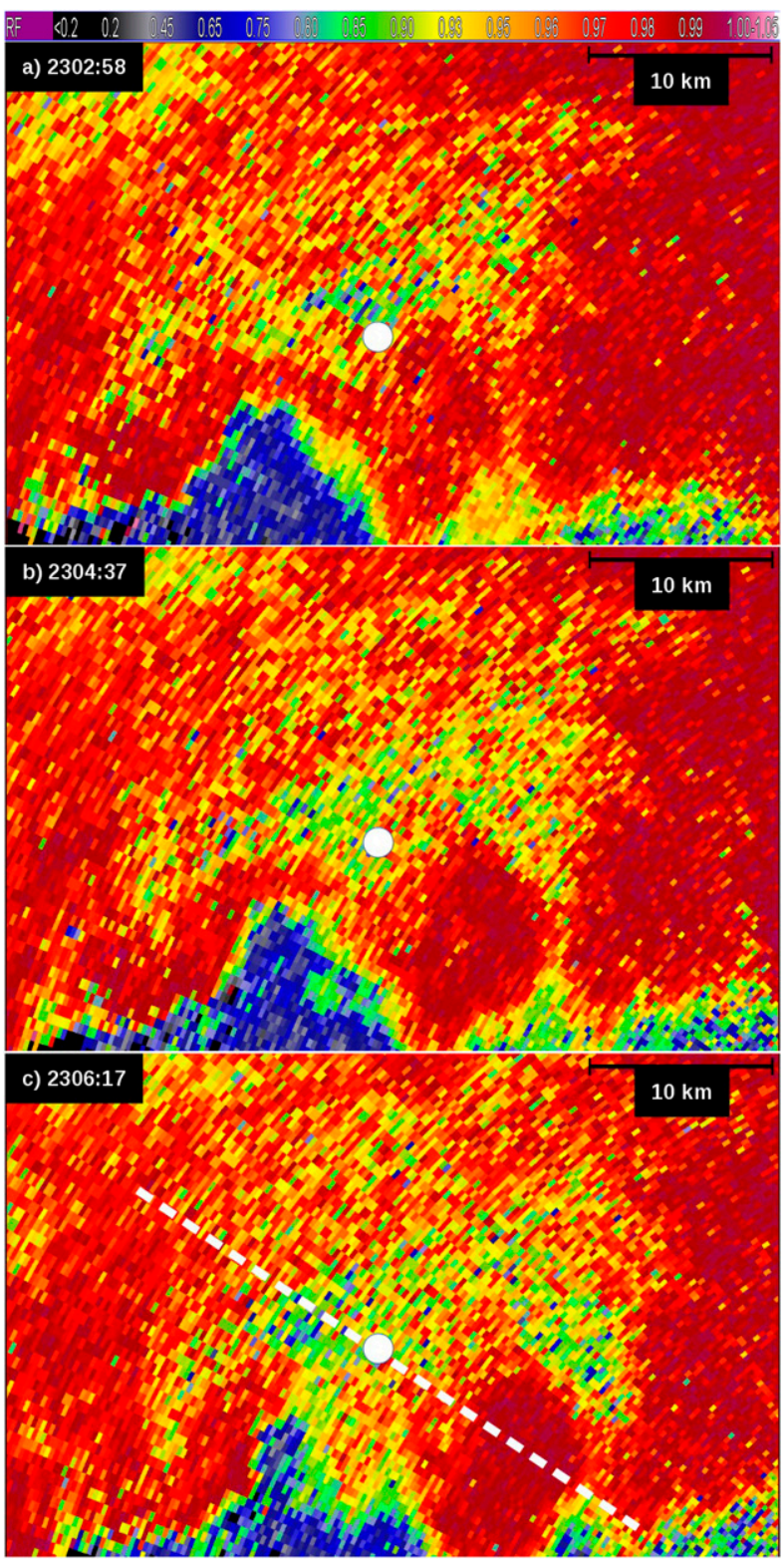

FIG. 16. As in Fig. 12, but for copolar correlation coefficient.

RFGH location is within a narrow channel of lower $Z_{\mathrm{DR}}$ (Fig. 18b) and lower $\rho_{\mathrm{HV}}$ (Fig. 18c) that curves cyclonically from the rear-flank core to the back side of the hook echo. Aloft, this location is at the back edge of the large $Z_{\mathrm{DR}}$ and $\rho_{\mathrm{HV}}$ columns (Figs. $19 \mathrm{~b}, \mathrm{c}$ and $20 \mathrm{~b}, \mathrm{c}$ ) that are associated with the primary updraft location. Observation of the $Z_{\mathrm{DR}}$ and $\rho_{\mathrm{HV}}$ columns is complicated by debris and precipitation that fill portions of the column area.

As with the FFGH, trends in low-altitude KOUN DP parameters near the RFGH are best seen in time series plots (Fig. 21). Low-altitude reflectivity is at a relative maximum during the giant hailfall, but the reflectivity is never higher than $45 \mathrm{dBZ}$. This is somewhat different than low-altitude reflectivity for the FFGH event, where a relative minimum occurs. Low-altitude $Z_{\mathrm{DR}}$ for the RFGH is similar to the FFGH event, as $Z_{\mathrm{DR}}$ falls from peak values before the giant hailfall to low values during the hailfalls, although minimum values for the RFGH $(\sim 1.7 \mathrm{~dB})$ are slightly higher than those for the FFGH $(\sim 1.0 \mathrm{~dB})$. The low-altitude $\rho_{\mathrm{HV}}$ for the RFGH event is more definitive; the decrease is less noisy than the FFGH event, with RFGH values falling below 0.9 . Trends in $K_{\mathrm{DP}}$ are also similar for the two giant hailfall events, with values falling during the hailfall, and minimum values becoming negative, perhaps indicative of complex scattering caused by the giant hail.

\section{Discussion}

A ground-breaking technique (so-called crowdsourcing by the ERSP) was used, and considerable effort expended, in searching for and tracking down observations of giant hail. The number of giant hail sources was increased from just one in the NCEI storm data to 13 in this study. Those 13 sources provided 17 observations because of time-to-space conversion of one video of giant hailfall that lasted $5 \mathrm{~min}$, with each minute of video treated as a separate observation. However, it is probable that additional giant hail fell in and around $\mathrm{El}$ Reno. In fact, six additional observations were identified (all within the two analyzed areas), but either key information was missing (e.g., hailfall time) or the observer could not be located and interviewed. Although the ERSP collected information after 2324 UTC, no additional giant hail reports were found, even though storm spotters/chasers were still gathered around the storm, and the storm moved into the more densely populated Oklahoma City metropolitan area. Hence, it is not unreasonable to assume that the El Reno Storm's giant hailfall diminished in amount, or ended, not long after 2324 UTC.

To better understand the relationship between features of the El Reno Storm radar echo and the giant hailfall, all giant hail observations were related to the supercell's primary midaltitude updraft (midaltitude defined here as $5 \mathrm{~km}$ ARL). The midaltitude updraft locations were manually obtained by choosing a location in each KOUN radar volume that was an average of the centroids of the BWER and the $Z_{\mathrm{DR}}$ and $\rho_{\mathrm{HV}}$ columns. The locations of the giant hailfall observations relative to the updraft center determined from the KOUN volume scan closest in time to the hail observation were then plotted (Fig. 22). The giant hail fell in a ring 6-10 km from the updraft center, near locations that were on the fringes of the BWER and $Z_{\mathrm{DR}} / \rho_{\mathrm{HV}}$ columns (Figs. 13, 19). All of the observed earlier giant hailfalls 

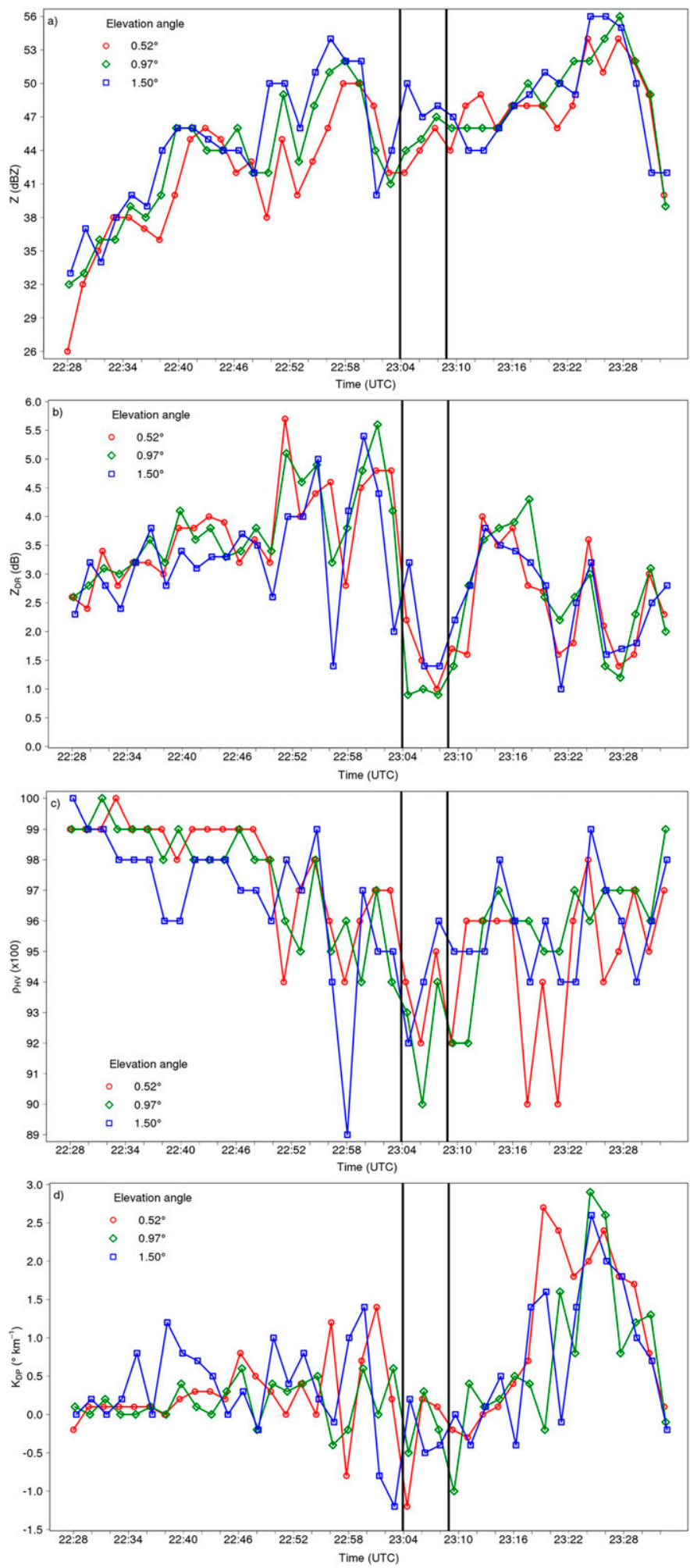

FIG. 17. Time series of low-altitude KOUN observations of (a) reflectivity $Z$, (b) differential reflectivity $Z_{\mathrm{DR}}$, (c) copolar correlation coefficient $\rho_{\mathrm{HV}}$, and (d) specific differential phase $K_{\mathrm{DP}}$ above the FFGH. The vertical black lines indicate the time period of the FFGH (2304-2309 UTC). The altitudes of the three elevation angles at the FFGH location are 0.7, 1.1 , and $1.7 \mathrm{~km}$ ARL. 

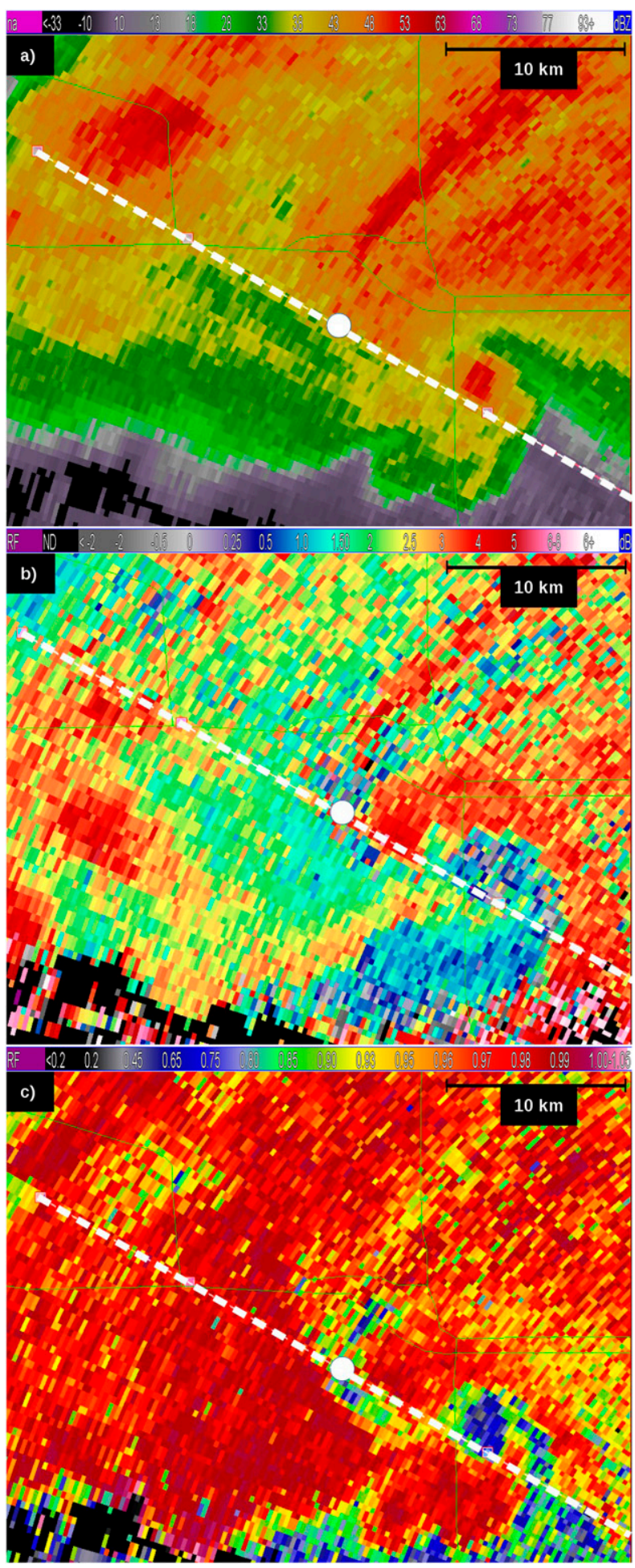

FIG. 18. KOUN $0.5^{\circ}$ scan at 2320:58 UTC of (a) reflectivity, (b) differential reflectivity, and (c) copolar correlation coefficient Dashed lines show location of the vertical cross sections in Fig. 20. The white circles show the location of the RFGH.
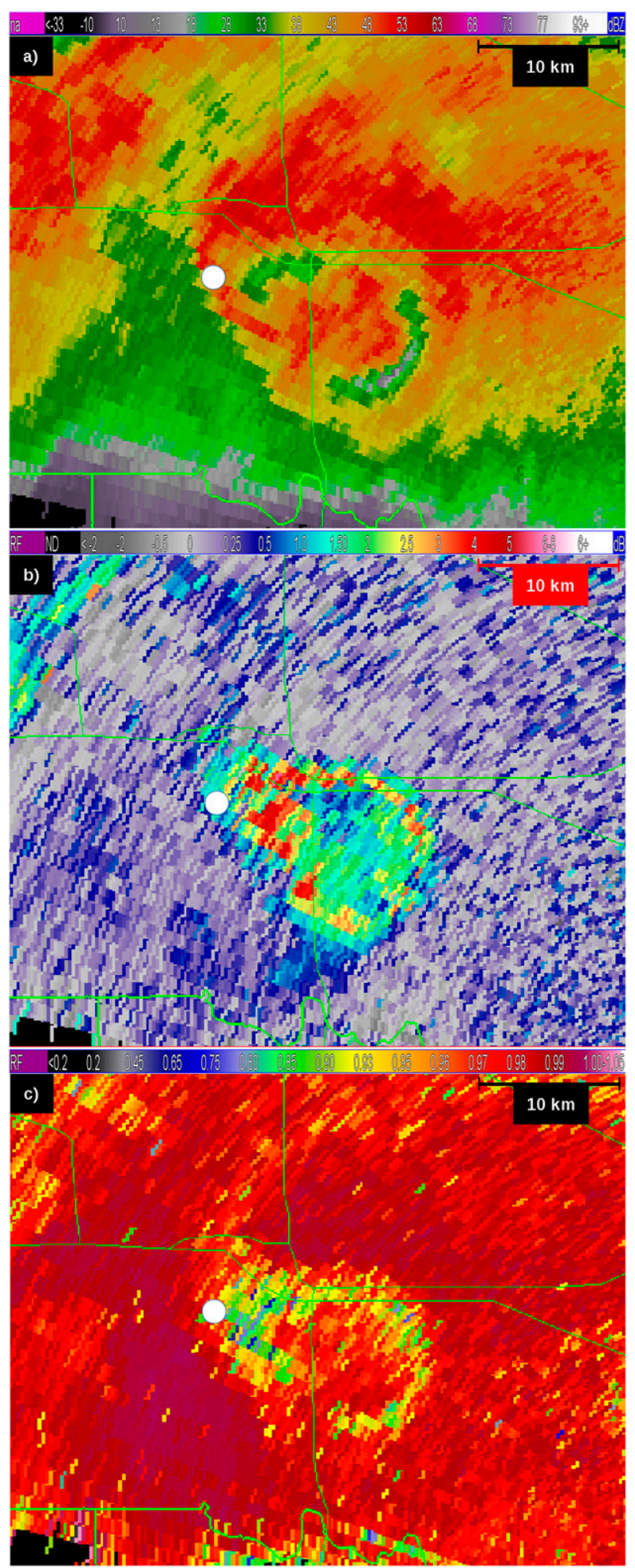

FIG. 19. KOUN horizontal cross sections at $5 \mathrm{~km}$ ARL of (a) reflectivity, (b) differential reflectivity, and (c) copolar correlation coefficient. The white circles show the location of the RFGH. The cross sections were derived from the KOUN volume scan collected from 2320:58 to 2322:35 UTC. 


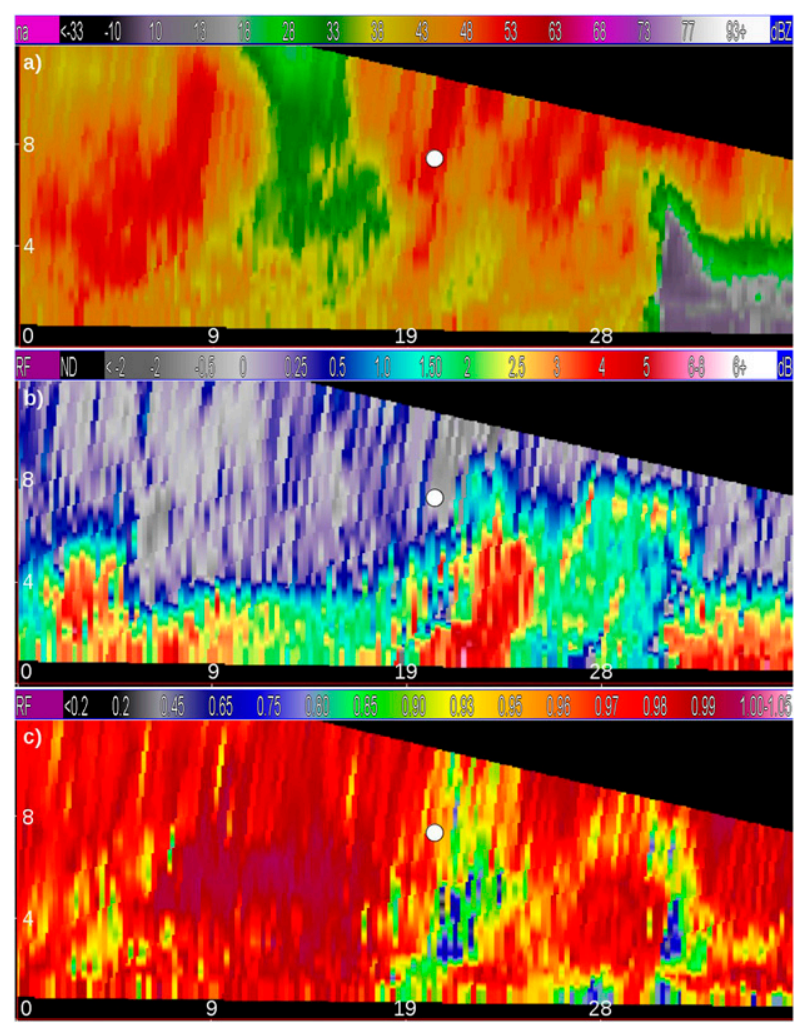

FIG. 20. KOUN vertical cross sections of (a) reflectivity, (b) differential reflectivity, and (c) copolar correlation coefficient. Horizontal distance and vertical height (shown via white numerals) are in kilometers. The white circles correspond to the location of the RFGH. The cross sections were derived from the KOUN volume scan collected from 2320:58 to 2322:35 UTC.

(FFGH) were along the northeast edge of the updraft, and all of the observed later giant hailfalls (RFGH) were along the southwest edge of the updraft (except for isolated report 6 , which is discussed below). However, with only a small sample size, it is possible that the full extent of giant hailfall was not as discrete as shown here and could have been distributed more evenly around the southwest to northeast sides of the updraft. These locations are consistent with long-held thoughts that hail should fall not at or near the center, but instead near the edge of the updraft (Browning and Foote 1976), and that the hailfall should be somewhat monodispersed, with the largest stones falling closest to the updraft center (Blair et al. 2012) and falling without attendant smaller hail or rain drops owing to size sorting.

One outlier in the analysis is giant hail observation 6 (see Fig. 22). This is the observation from within the tornado path and south of the center of the tornado. Although its trajectory is not known, it could be speculated that as this hailstone fell, it was horizontally advected in the converging, strong rotational winds within the low-altitude mesocyclone and was carried to a location within the tornado. Since the time of the report (2313 UTC) is between the times of the two known giant hailfalls, its occurrence might mean the actual hailswath of giant stones was more continuous than reported here. Or, perhaps its fall trajectory was simply more singular and unique in origin.

\section{Conclusions}

The threat to life and property associated with a severe storm increases at a nonlinear rate as the intensity of the storm increases. Hence, timely identification of and warning for the occurrence of extreme severe weather events, such as strong tornadoes and giant hail, is vital. The El Reno Storm of 31 May 2013 is a classic example of such an event: a supercell producing a very strong tornado and giant hail. Information on the tornado has been presented by previous authors. However, the giant hailfall has escaped detailed examination until now. The occurrence of near-record-size hail for Oklahoma, from 13 to $16 \mathrm{~cm}$ (5-6.3 in.) in diameter, within $60 \mathrm{~km}$ of two fixed-site research radars (PAR and KOUN) and briefly within $5 \mathrm{~km}$ of a mobile research radar ( $\mathrm{RaXPol}$ ), provided the opportunity to examine the evolution of the storm that produced the giant hail and show details of the polarimetric signatures associated with the storm's giant hailfalls. The analysis presented herein has better temporal resolution than is possible from operational radars scanning at lower update rates. The use of crowd sourcing and other social media data-gathering methods in this study suggest that the future of storm-event reporting is likely to change from including only traditional NWS methods (storm spotters, law enforcement, emergency management, etc.) to adding significant input from social media (Allen and Tippett 2015). However, the scope, scale, and techniques of the ERSP are probably beyond the resources available to local NWS offices.

Given the extreme environmental conditions on 31 May 2013, it is not surprising that the El Reno Storm rapidly intensified after the first echo. Following the initial rapid-growth phase, there was a quasi-steady phase modulated by cycles associated with multiple updrafts and storm mergers. After one last merger with a storm cell to its south, the El Reno Storm again increased in intensity, becoming a classic supercell about $40 \mathrm{~min}$ before the concurrent development of the strong tornado and the first report of giant hail. During the 40-min period of the tornado and the known 20-min period of giant hailfall, the El Reno Storm exhibited classic supercellular features and exceptional radar-measured intensities. The STD maximum of $158 \mathrm{~m} \mathrm{~s}^{-1}$ is similar to 

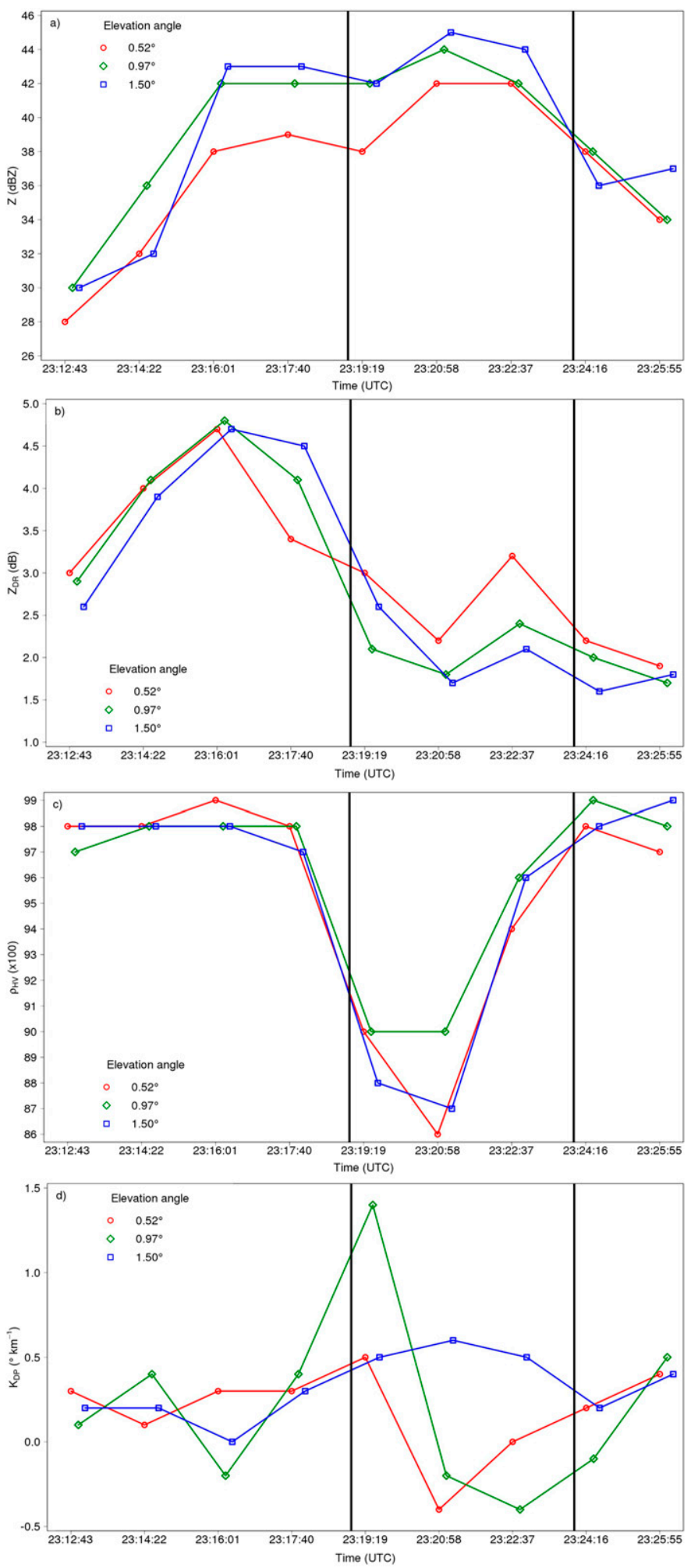

FIG. 21. As in Fig. 17, except above the RFGH. The altitudes of the three elevation angles at the RFGH location are $0.7,1.2$, and $1.7 \mathrm{~km}$ ARL. 


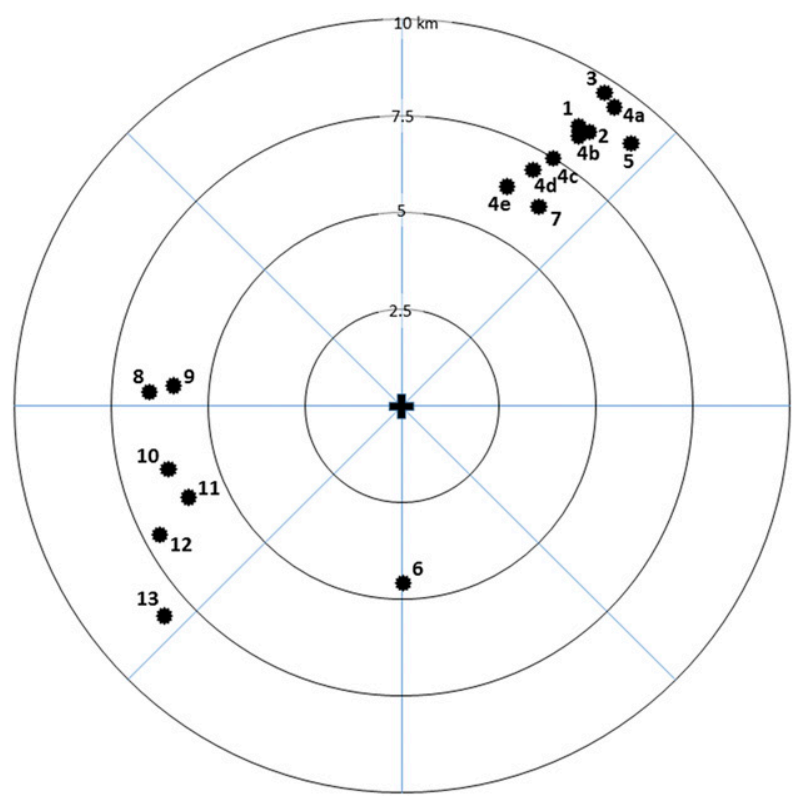

FIG. 22. Locations of the giant hailstone observations relative to the center of the main storm updraft.

the extreme STD maximum of $157 \mathrm{~m} \mathrm{~s}^{-1}$ seen in the Ft. Cobb, Oklahoma, storm of 18 June 1973 (Lemon and Burgess 1980). There were also multiple instances when inbound radial velocities in the STD signature were $>100 \mathrm{~m} \mathrm{~s}^{-1}$, eclipsing the $97 \mathrm{~m} \mathrm{~s}^{-1}$ observed in the Ft. Cobb storm. The $158 \mathrm{~m} \mathrm{~s}^{-1}$ STD value is also more than double the median maximum value of $72 \mathrm{~m} \mathrm{~s}^{-1}$ from a dataset of STD observations of storms producing giant hail (Blair et al. 2011). That only two such extreme STD maximums $>155 \mathrm{~m} \mathrm{~s}^{-1}$ have been documented over a time period $>40$ years could be due to 1 ) a storm of this type being very rare, 2) a lack of focus on or good documentation in the literature of STD measurements, and/or 3) better resolution radar data for this event. Similar to STD, the maximum of $54.5 \mathrm{~m} \mathrm{~s}^{-1}$ for mesocyclone midaltitude rotational velocity (MRV) in the El Reno Storm is more than double the median value of $24.5 \mathrm{~m} \mathrm{~s}^{-1}$ within storms producing giant hail (Blair et al. 2011). The El Reno Storm mesocyclone also ranks at the top of a large dataset of low-altitude rotational velocity measurements (Smith et al. 2015).

Although calculations of the velocity-based parameters were at or near record values, this was not the case for the reflectivity-based parameters. Despite very large MESH maxima $(12 \mathrm{~cm})$ before 2300 UTC, MESH values during the giant hailfall (2304-2324 UTC) decreased from 9 to $5-6 \mathrm{~cm}$, suggesting that the giant hailfalls likely were associated with an elevated hail core that developed prior to 2304 UTC and then fell out of the storm afterward. Likewise, neither VIL nor $Z_{253 \mathrm{~K}}$ were at storm peak values during the observed giant hailfall. Moreover, the maximum MESH values calculated for the El Reno Storm were not collocated with the giant hailfall, but were located farther to the north and west in the more traditional rear-flank core area (not shown). This difference can be explained because MESH uses integrated values of reflectivity above the melting level, which were not highest along the fringes of the BWER and polarimetric columns representing the updraft location. This demonstrates the need for warning forecasters to understand the functionality of severe weather algorithms such as MESH and to not rely on a single radar parameter, but to utilize all available information in the warning decision-making process.

For reasons described in section $2 \mathrm{a}$, it was not possible to determine if giant hail fell during much of the supercell phase of the El Reno Storm. The sparse population and lack of storm spotters focusing on hail reports prevent knowledge of the extent and intensity of the hailfall along the storm track southwest of El Reno. Only as the storm approached the more-populated El Reno area, and as storm spotters began documenting the tornado, did it become possible to obtain giant hailfall information. The lack of more complete observation of the entire hailswath from the El Reno Storm prevents knowledge of the actual extent of giant hailfall, except for a relatively short time period (2304-2324 UTC), and is a limitation of this study. As has been seen in other studies (Payne et al. 2010; Blair et al. 2012), the observed giant hail occurred outside the main precipitation core. The low-altitude reflectivities associated with both the FFGH and RFGH areas were 40-50 dBZ [similar to those seen by Blair et al. (2012) for maximum hail diameters $>10 \mathrm{~cm}$ ], whereas reflectivities in the core north of the giant hailfalls were in the $60-70 \mathrm{~dB} Z$ range. The observed giant hail was associated with $10-\mathrm{cm}$-wavelength DP signatures consistent with past observations of large hail, namely, low $Z_{\mathrm{DR}}$, low $\rho_{\mathrm{HV}}$, and low $K_{\mathrm{DP}}$ (Payne et al. 2010; Picca and Ryzhkov 2012; Smyth et al. 1999; Snyder et al. 2014). For the FFGH, this was most readily seen in the pattern of $Z_{\mathrm{DR}}$, whereas for the $\mathrm{RFGH}$, this was most readily seen in the pattern of $\rho_{\mathrm{HV}}$. With respect to the structure of the supercell, the giant hail fell along both the northeast and southwest edges of the midaltitude primary storm updraft as defined by the BWER and the locations of the $Z_{\mathrm{DR}}$ and $\rho_{\mathrm{HV}}$ columns. For the El Reno Storm, this meant that giant hail fell at ranges of $6-10 \mathrm{~km}$ from the main updraft center. The giant hail also fell to the northeast (FFGH) and northwest (RFGH) of the large, violent El Reno tornado and the storm's deep, intense mesocyclone. The exception was a lone report of giant hail within the circulation of the tornado, perhaps falling 
from the RFGH area and getting caught in the converging, rotational winds of the low-altitude mesocyclone.

Hopefully, this study will help to generate more interest in documenting the locations and characteristics of other giant hailfalls. Unfortunately, for this event, without the preplanning of hail observation platforms to record the hailfall and/or a comprehensive survey immediately after the event (e.g., HailSTONE; Blair et al. 2017), it was only possible to document the giant hail that fell during a portion of the life of the El Reno Storm. A more complete knowledge of the time and location of giant hail could aid in attempts to better understand supercell morphology and assist with more specific warnings to the public.

Acknowledgments. The authors thank Charles Kuster, Harald Richter, Terry Schuur, and two anonymous reviewers for providing numerous beneficial suggested modifications to the original manuscript. A. Seimon and J. T. Allen acknowledge National Geographic Grant EC0781-16 in support of the El Reno Survey Project and thank the multitude of individuals who voluntarily contributed valuable data. H. Bluestein acknowledges NSF Grant AGS-1560945 for support of RaXPol field operations and data analysis. Jana Houser (Ohio University) assisted with RaXPol data collection. The Advanced Radar Research Center (ARRC) at the University of Oklahoma maintained RaXPol.

\section{REFERENCES}

Allen, J. T., and M. K. Tippett, 2015: The characteristics of United States hail reports: 1955-2014. Electron. J. Severe Storms Meteor., 10 (3), http://www.ejssm.org/ojs/index.php/ejssm/article/viewArticle/149.

Amburn, S. A., and P. L. Wolf, 1997: VIL density as a hail indicator. Wea. Forecasting, 12, 473-478, https://doi.org/10.1175/ 1520-0434(1997)012<0473:VDAAHI >2.0.CO;2.

Blair, S. F., and J. W. Leighton, 2012: Creating high-resolution hail datasets using social media and post-storm ground surveys. Electron. J. Oper. Meteor., 13, 32-45.

—, D. R. Deroche, J. M. Boustead, J. W. Leighton, B. L. Barjenbruch, and W. P. Gargan, 2011: A radar-based assessment of the detectability of giant hail. Electron. J. Severe Storms Meteor., 6 (7), http://www.ejssm.org/ojs/index.php/ejssm/article/view/87.

_- J. M. Laflin, J. W. Leighton, and D. R. Deroche, 2012: S-band polarimetric analysis of the 23 May 2011 Oklahoma record hailstorm using high-resolution observations during HailSTONE. 26th Conf. on Severe Local Storms, Nashville, TN, Amer. Meteor. Soc., 16.6, https://ams.confex.com/ams/ 26SLS/webprogram/Paper211473.html.

_ , and Coauthors, 2017: High-resolution hail observations: Implications for NWS warning operations. Wea. Forecasting, 32, 1101-1119, https://doi.org/10.1175/WAF-D-16-0203.1.

Bluestein, H. B., J. C. Snyder, and J. B. Houser, 2015: A multiscale overview of the El Reno, Oklahoma, tornadic supercell of 31 May 2013. Wea. Forecasting, 30, 525-552, https://doi.org/ 10.1175/WAF-D-14-00152.1.
— K. J. Thiem, J. C. Snyder, and J. B. Houser, 2018: The multiplevortex structure of the El Reno, Oklahoma, tornado on 31 May 2013. Mon. Wea. Rev., 146, 2483-2502, https://doi.org/10.1175/ MWR-D-18-0073.1.

Brown, R. A., and V. T. Wood, 2007: A guide for interpreting Doppler velocity patterns: Northern Hemisphere edition. NOAA Tech. Rep., 61 pp., https://www.nssl.noaa.gov/publications/ dopplerguide/Doppler\%20Guide\%202nd\%20Ed.pdf.

Browning, K. A., 1977: The structure and mechanisms of hailstorms. Hail: A Review of Hail Science and Hail Suppression, Meteor. Monogr., No. 38, Amer. Meteor. Soc., 1-47, https:// doi.org/10.1007/978-1-935704-30-0.

, and G. B. Foote, 1976: Airflow and hail growth in supercell storms and some implications for hail suppression. Quart. J. Roy. Meteor. Soc., 102, 499-533, https://doi.org/10.1002/qj.49710243303.

Changnon, S. A., 2009: Increasing major hail losses in the U.S. Climatic Change, 96, 161-166, https://doi.org/10.1007/s10584009-9597-z.

— costly on record. Mon. Wea. Rev., 131, 1734-1739, https:// doi.org/10.1175//2549.1.

Doswell, C. A., III, and D. W. Burgess, 1993: Tornadoes and tornadic storms: A review of conceptual models. The Tornado: Its Structure, Dynamics, Prediction, and Hazards, Geophys. Monogr., Vol. 79, Amer. Geophys. Union, 161-172, https:// doi.org/10.1029/GM079p0161.

Fabry, F., 2015: Radar Meteorology: Principles and Practice. Cambridge University Press, 272 pp., https://doi.org/10.1017/ CBO9781107707405.

Heinselman, P. L., and S. M. Torres, 2011: High-temporalresolution capabilities of the National Weather Radar Testbed phased-array radar. J. Appl. Meteor. Climatol., 50, 579-593, https://doi.org/10.1175/2010JAMC2588.1.

Kelly, D. L., J. T. Schaefer, and C. A. Doswell III, 1985: Climatology of nontornadic severe thunderstorm events in the United States. Mon. Wea. Rev., 113, 1997-2014, https://doi.org/ 10.1175/1520-0493(1985)113<1997:CONSTE > 2.0.CO;2.

Kumjian, M. R., 2013: Principles and applications of dualpolarization weather radar. Part I: Description of the polarimetric radar variables. J. Oper. Meteor., 1, 226-242, https:// doi.org/10.15191/nwajom.2013.0119.

, and A. V. Ryzhkov, 2008: Polarimetric signatures in supercell thunderstorms. J. Appl. Meteor. Climatol., 47, 1940-1961, https://doi.org/10.1175/2007JAMC1874.1.

- J. Snyder, A. V. Ryzhkov, D. S. Zrnić, S. Frasher, and H. B. Bluestein, 2008: Comparison of polarimetric radar observations of tornadic supercells at S, C, and X bands. 24th Conf. on Severe Local Storms, Savannah, GA, Amer. Meteor. Soc., 5.5, https:// ams.confex.com/ams/24SLS/techprogram/paper_142020.htm.

Kuster, C. M., P. L. Heinselman, and M. Austin, 2015: 31 May 2013 El Reno tornadoes: Advantages of rapid-scan phased-array radar data from a warning forecaster's perspective. Wea. Forecasting, 30, 933-956, https://doi.org/10.1175/WAF-D-14-00142.1.

Lakshmanan, V., T. Smith, K. Hondl, G. J. Stumpf, and A. Witt, 2006: A real-time, three-dimensional, rapidly updating, heterogeneous radar merger technique for reflectivity, velocity, and derived products. Wea. Forecasting, 21, 802-823, https:// doi.org/10.1175/WAF942.1.

$\longrightarrow,-$ - G. Stumpf, and K. Hondl, 2007: The Warning Decision Support System-Integrated Information. Wea. Forecasting, 22, 596-612, https://doi.org/10.1175/WAF1009.1.

Lemon, L. R., and D. W. Burgess, 1980: Magnitude and implications of high speed outflow at severe storm summits. Preprints, 
19th Conf. on Radar Meteorology, Miami Beach, FL, Amer. Meteor. Soc., 364-368.

Markowski, P., and Y. Richardson, 2014: What we know and don't know about tornado formation. Phys. Today, 67, 26-31, https://doi.org/10.1063/PT.3.2514.

National Centers for Environmental Information, 2013: Storm data. Accessed 24 July 2018, https://www.ncdc.noaa.gov/IPS/ sd/sd.html.

National Weather Service, 2014: Service assessment: May 2013 Oklahoma tornadoes and flash flooding. NWS Tech. Rep., 63 pp., https:/www.weather.gov/media/publications/assessments/ 13oklahoma_tornadoes.pdf.

Nelson, S. P., 1983: The influence of storm flow structure on hail growth. J. Atmos. Sci., 40, 1965-1983, https://doi.org/10.1175/ 1520-0469(1983)040<1965:TIOSFS $>2.0$. CO; 2 .

Payne, C. D., C. A. V. D. Broeke, L. R. Lemon, and P. T. Schlatter, 2010: Polarimetric radar characteristics of a supercell hailstorm on 10 May 2010 in central Oklahoma. 25th Conf. on Severe Local Storms, Denver, CO, Amer. Meteor. Soc., P8.7, https:// ams.confex.com/ams/25SLS/techprogram/Paper_175763.htm.

Pazmany, A. L., J. B. Mead, H. B. Bluestein, J. C. Snyder, and J. B. Houser, 2013: A mobile rapid-scanning X-band polarimetric (RaXPol) Doppler radar system. J. Atmos. Oceanic Technol., 30, 1398-1413, https://doi.org/10.1175/JTECH-D-12-00166.1.

Picca, J., and A. Ryzhkov, 2012: A dual-wavelength polarimetric analysis of the 16 May 2010 Oklahoma City extreme hailstorm. Mon. Wea. Rev., 140, 1385-1403, https://doi.org/10.1175/ MWR-D-11-00112.1.

Pojorlie, K. L., S. Doering, and M. A. Fowle, 2013: The record-breaking Vivian, South Dakota, hailstorm of 23 July 2010. J. Oper. Meteor., 1, 3-18, https://doi.org/10.15191/nwajom.2013.0102.

Rasmussen, E. N., and J. M. Straka, 1998: Variations in supercell morphology. Part I: Observations of the role of upper-level storm-relative flow. Mon. Wea. Rev., 126, 2406-2421, https:// doi.org/10.1175/1520-0493(1998)126<2406:VISMPI >2.0.CO;2.

Ryzhkov, A. V., M. R. Kumjian, S. M. Ganson, and A. P. Khain, 2013: Polarimetric radar characteristics of melting hail. Part I: Theoretical simulations using spectral microphysical modeling. J. Appl. Meteor. Climatol., 52, 2849-2870, https://doi.org/ 10.1175/JAMC-D-13-073.1.

Seimon, A., J. T. Allen, T. A. Seimon, S. J. Talbot, and D. K. Hoadley, 2016: Crowdsourcing the El Reno 2013 tornado: A new approach for collation and display of storm chaser imagery for scientific applications. Bull. Amer. Meteor. Soc., 97, 2069-2084, https://doi.org/10.1175/BAMS-D-15-00174.1.

Smith, B. T., R. L. Thompson, A. R. Dean, and P. T. Marsh, 2015: Diagnosing the conditional probability of tornado damage rating using environmental and radar attributes. Wea. Forecasting, 30, 914-932, https://doi.org/10.1175/WAF-D-14-00122.1.

Smyth, T. J., T. M. Blackman, and A. J. Illingworth, 1999: Observations of oblate hail using dual polarization radar and implications for hail-detection schemes. Quart. J. Roy. Meteor. Soc., 125, 993-1016, https://doi.org/10.1002/qj.49712555512.

Snyder, J. C., and H. B. Bluestein, 2014: Some considerations for the use of high-resolution mobile radar data in tornado intensity determination. Wea. Forecasting, 29, 799-827, https:// doi.org/10.1175/WAF-D-14-00026.1.

, ——, G. Zhang, and S. J. Frasier, 2010: Attenuation correction and hydrometeor classification of high-resolution, X-band, dual-polarized mobile radar measurements in severe convective storms. J. Atmos. Oceanic Technol., 27, 1979-2001, https://doi.org/10.1175/2010JTECHA1356.1.
—, A. V. Ryzhkov, H. B. Bluestein, and S. F. Blair, 2014: Polarimetric analysis of two giant-hail-producing supercells observed by X-band and S-band radars. 27th Conf. on Severe Local Storms, Madison, WI, Amer. Meteor. Soc., 166, https:// ams.confex.com/ams/27SLS/webprogram/Paper255455.html.

,-- _ M. R. Kumjian, A. P. Khain, and J. Picca, 2015: A $Z_{\mathrm{DR}}$ column detection algorithm to examine convective storm updrafts. Wea. Forecasting, 30, 1819-1844, https://doi.org/ 10.1175/WAF-D-15-0068.1.

- , H. B. Bluestein, D. T. Dawson II, and Y. Jung, 2017: Simulations of polarimetric, X-band radar signatures in supercells. Part I: Description of experiment and simulated $\rho_{\mathrm{HV}}$ rings. J. Appl. Meteor. Climatol., 56, 1977-1999, https://doi.org/ 10.1175/JAMC-D-16-0138.1.

Tanamachi, R. L., and P. L. Heinselman, 2016: Rapid-scan, polarimetric observations of central Oklahoma severe storms on 31 May 2013. Wea. Forecasting, 31, 19-42, https://doi.org/ 10.1175/WAF-D-15-0111.1.

Thuras, D., 2010: Hail no: An account of the worlds biggest, deadliest hailstorms. Atlas Obscura, accessed 24 July 2018 , http://www.atlasobscura.com/articles/hail-no-an-account-ofthe-worlds-biggest-deadliest-hailstorms.

Torres, S. M., and Coauthors, 2016: Adaptive-weather-surveillance and multifunction capabilities of the National Weather Radar Testbed phased array radar. Proc. IEEE, 104, 660-672, https:// doi.org/10.1109/JPROC.2015.2484288.

Wakimoto, R. M., and Coauthors, 2016: Aerial damage survey of the 2013 El Reno tornado combined with mobile radar data. Mon. Wea. Rev., 144, 1749-1776, https://doi.org/10.1175/ MWR-D-15-0367.1.

Witt, A., 1996: The relationship between low-elevation WSR-88D reflectivity and hail at the ground using precipitation observations from the VORTEX project. Preprints, 18th Conf. on Severe Local Storms, San Francisco, CA, Amer. Meteor. Soc., 183-185. , 1998: The relationship between WSR-88D measured midaltitude rotation and maximum hail size. Preprints, 19th Conf. on Severe Local Storms, Minneapolis, MN, Amer. Meteor. Soc., 740-743.

- 2014: High-resolution phased array radar observations of an Oklahoma hailstorm producing extremely-large hail. 27th Conf. on Severe Local Storms, Madison, WI, Amer. Meteor. Soc., 165, https://ams.confex.com/ams/27SLS/webprogram/ Paper253994.html.

—_ and S. P. Nelson, 1991: The use of single-Doppler radar for estimating maximum hailstone size. J. Appl. Meteor., 30, 425-431, https://doi.org/10.1175/1520-0450(1991)030<0425: TUOSDR $>2.0 . \mathrm{CO} ; 2$.

—, M. D. Eilts, G. J. Stumpf, J. T. Johnson, E. D. W. Mitchell, and K. W. Thomas, 1998: An enhanced hail detection algorithm for the WSR-88D. Wea. Forecasting, 13, 286-303, https://doi.org/ 10.1175/1520-0434(1998)013<0286:AEHDAF>2.0.CO;2.

- D. W. Burgess, A. Seimon, and J. T. Allen, 2015: Rapid-scan dual-polarization WSR-88D observations of an Oklahoma hailstorm producing extremely-large hail. 37th Conf. on Radar Meteorology, Norman, OK, Amer. Meteor. Soc., 134, https://ams.confex.com/ams/37RADAR/webprogram/ Paper275689.html.

Wurman, J., K. Kosiba, and P. Robinson, 2014: The role of multiple-vortex tornado structure in causing storm researcher fatalities. Bull. Amer. Meteor. Soc., 95, 31-45, https://doi.org/ 10.1175/BAMS-D-13-00221.1.

Zrnić, D. S., and Coauthors, 2007: Agile-beam phased array radar for weather observations. Bull. Amer. Meteor. Soc., 88, 17531766, https://doi.org/10.1175/BAMS-88-11-1753. 